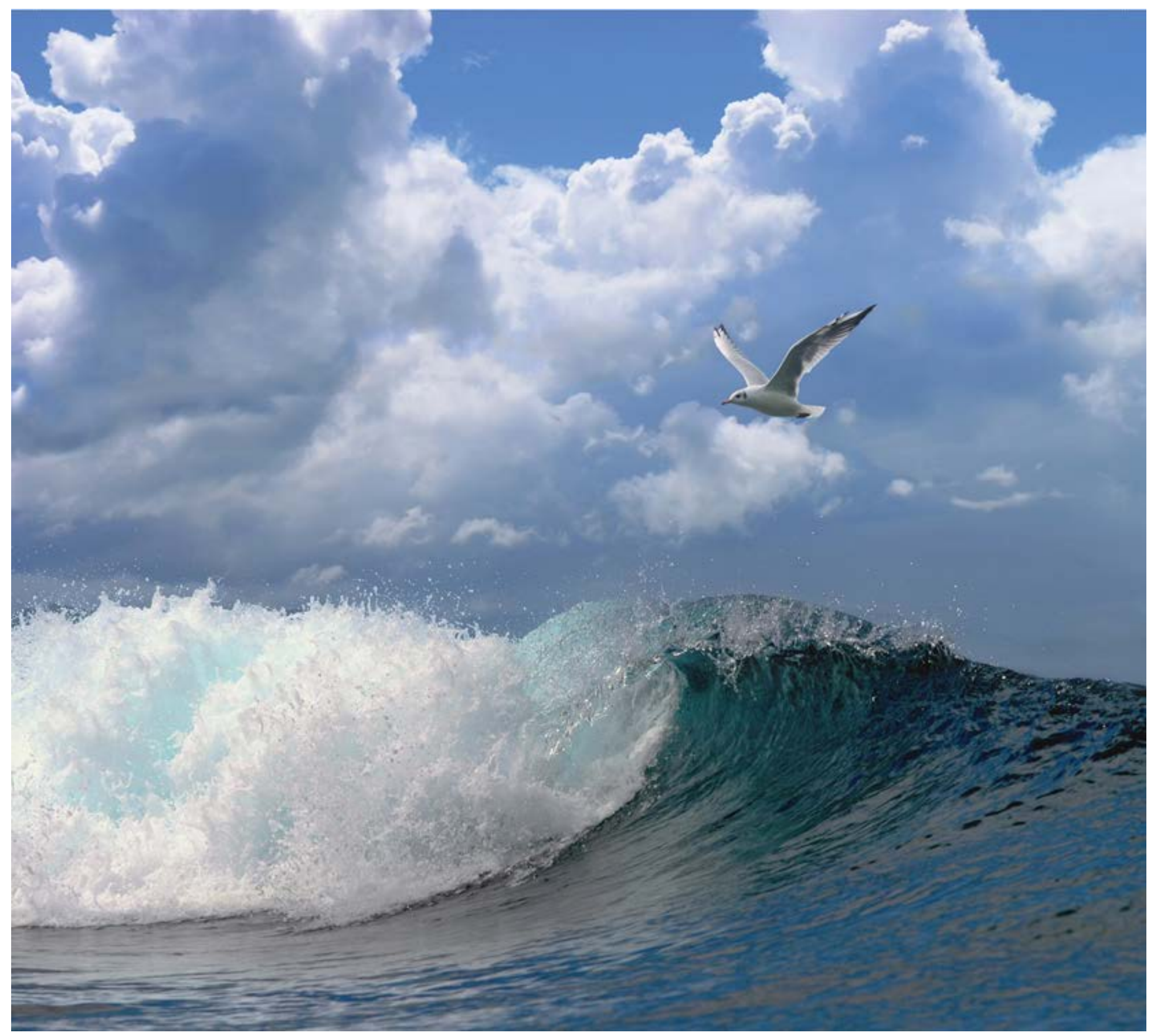

Stapels bruinvissen! Hoe verhoudt een snelle massa-sectie zich tot het lopende dieet-onderzoek? 


\section{Stapels bruinvissen! Hoe verhoudt een snelle massa-sectie zich tot het lopende dieet-onderzoek?}

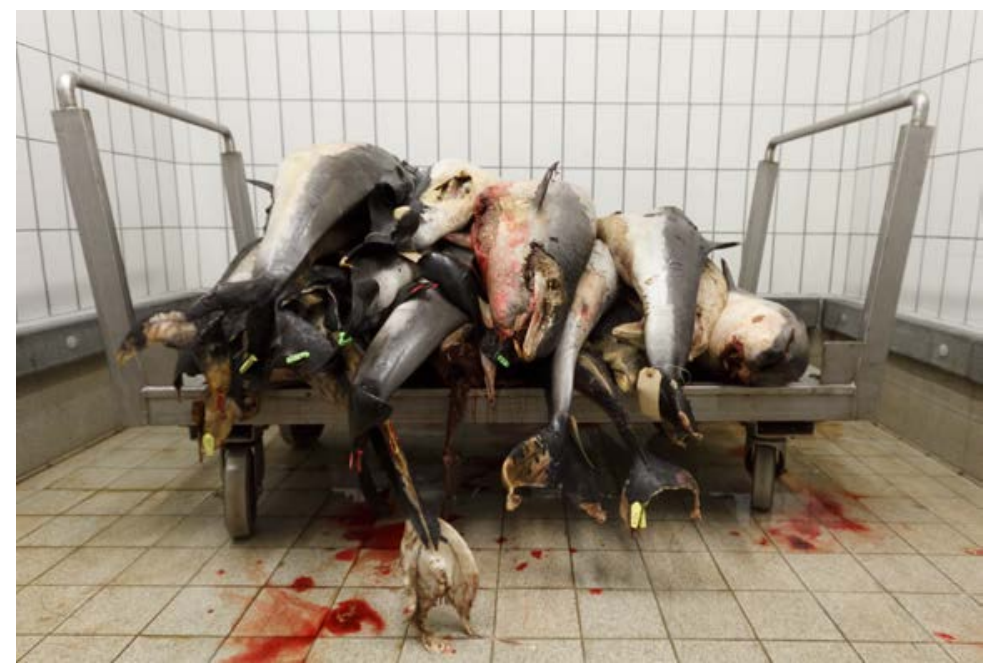

Auteur(s):

Opdrachtgever:
Amy Mairo, Mardik Leopold

Ministerie van LNV

T.a.v. drs ing. M.W.F. Peijs

Bezuidenhoutseweg 73, 2500 EK Den Haag

BO-11-011.04-041, HD3510 (2014)

\section{Publicatie datum: April 2018}

Dit onderzoek is uitgevoerd door Wageningen Marine Research in opdracht van en gefinancierd door het Ministerie van LNV, in het kader van het Beleidsondersteunend onderzoekthema 'Mariene Biodiversiteit' (projectnummer BO-11-011.04-041, jaar 2014) 
Amy Mairo, Mardik Leopold , 2018. Stapels bruinvissen! Hoe verhoudt een snelle massa-sectie zich tot het lopende dieet-onderzoek? Wageningen, Wageningen Marine Research, Wageningen Marine Research rapport C032/18. 37 blz.; 21 tab.; 62 ref.

$\begin{array}{ll}\text { Naam } & \text { Amy Mairo } \\ \text { Departement } & \text { Aeres Hogeschool Almere } \\ \text { Specialisatie } & \text { Toegepaste Biologie (Applied Biology) } \\ \text { Supervisie } & \text { Mardik Leopold } \\ \text { Plaats } & \text { Den Helder } \\ \text { Datum } & 24 / 04 / 2017-15 / 09 / 2017\end{array}$

Cover foto: Een stapel bruinvissen (Pieter Crucq Digital Media)

Dit rapport is gratis te downloaden van https://doi.org/10.18174/448545

Wageningen Marine Research verstrekt geen gedrukte exemplaren van rapporten.

(c) 2017 Wageningen Marine Research

Wageningen Marine Research, onderdeel van Stichting DLO.

KvK nr. 09098104,

IMARES BTW nr. NL 8113.83.696.B16

Code BIC/SWIFT address: RABONL2U

IBAN code: NL 73 RABO 0373599285
De Directie van Wageningen Marine Research is niet aansprakelijk voor gevolgschade, noch voor schade welke voortvloeit uit toepassingen van de resultaten van werkzaamheden of andere gegevens verkregen van IMARES; opdrachtgever vrijwaart IMARES van aanspraken van derden in verband met deze toepassing.

Niets uit dit rapport mag weergegeven en/of gepubliceerd worden, gefotokopieerd of op enige andere manier gebruikt worden zonder bronvermelding. 


\section{Inhoud}

$1 \quad$ Samenvatting $\quad 4$

2 Summary $r$

$\begin{array}{llr}3 & \text { Inleiding } & 6\end{array}$

3.1 Massa-secties op "boventallige" bruinvissen $\quad 6$

3.2 De bruinvis 7

$\begin{array}{lll}3.2 .1 & \text { Dieet } & 8\end{array}$

$\begin{array}{lr}3.2 .2 \text { Vijanden } & 8 \\ \text { Dieet-onderzoek } & 8\end{array}$

4 Opdracht $\quad 9$

4.1 Hypothese secties $\quad 9$

$\begin{array}{lr}4.2 & \text { Hypothese maagonderzoek }\end{array}$

5 Methode $r \begin{aligned} & 10\end{aligned}$

5.1 Secties 10

5.2 Data-exploratie 10

$\begin{array}{ll}\text { 5.2.1 Jaarlijks/ maandelijks aantal magen } & 10\end{array}$

5.2.2 Geslachten 13

5.2.3 Leeftijden 13

5.2.4 NCC (Voedingstoestand) 14

$\begin{array}{ll}5.2 .5 & \text { DCC (Mate van decompositie) }\end{array}$

5.2.6 Doodsoorzaken $\quad 15$

$\begin{array}{lll}5.2 .7 & \text { Locaties } & 15\end{array}$

5.2.8 Overgebleven magen na de selecties $\quad 15$

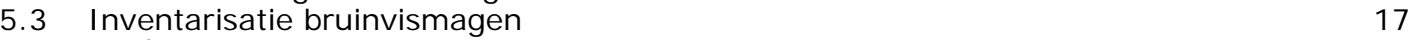

5.4 Analyses 18

$\begin{array}{lll}5.4 .1 & \text { T-toets } & 18\end{array}$

$\begin{array}{lll}5.4 .2 & \text { PERMANOVA } & 18\end{array}$

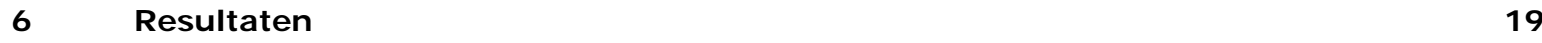

$\begin{array}{llr}6.1 & \text { Prooigroepen } & 19\end{array}$

6.2 Lege magen 22

$\begin{array}{ll}\text { 6.2.1 NCC (Voedingstoestand) } & 22\end{array}$

6.2.2 DCC (Decompositie) 23

6.3 Gevulde magen 24

6.3.1 Massa maaginhoud van juveniele dieren uit de jaren 2011, 2012 en $2013 \quad 24$

6.4 Dieet

$\begin{array}{lll}6.5 & \text { PERMANOVA analyse } & 30\end{array}$

7 Discussie $\quad 31$

$\begin{array}{lll}7.1 & \text { Inventarisatie- en verwerkingsprocedures } & 31\end{array}$

7.2 Resultaten 32

8 Conclusie $\quad 33$

$9 \quad$ Literatuur $\quad 34$ 


\section{Samenvatting}

De Noordzee is voor de bruinvis (Phocoena phocoena) in Europa een zeer belangrijk gebied. Ongeveer de helft van alle bruinvissen ter wereld leeft in de Noordzee. De bruinvis is in de Europese Unie een beschermde diersoort onder de Habitatrichtlijn en de regeringen van de Noordzee landen dienen de status van de soort in hun wateren te monitoren. In Nederland worden, op instigatie van het Ministerie van LNV, telingen van bruinvissen gedaan op zee en worden dieren die dood op de kust aanspoelen pathologisch onderzocht om de gezondheidstoestand van de populatie te kunnen volgen en om doodsoorzaken in kaart te kunnen brengen. In het verlengde van het pathologisch onderzoek wordt ook de maaginhoud van deze dieren onderzocht, om na te kunnen gaan welke soorten en maten van vissen door bruinvissen in Nederland worden gegeten. Het gecombineerde pathologische en dieetonderzoek loopt sinds 2006. In het eerste jaar werden 64 bruinvissen onderzocht; in de jaren daarna steeds tussen de circa 100 en 200. In de jaren 2011-2013 spoelden er ongekend grote aantallen dode bruinvissen aan in Nederland, en werden meer dode bruinvissen dan ooit voor onderzoek verzameld. Omdat er onvoldoende middelen beschikbaar waren om al deze verzamelde karkassen te onderzoeken, ontstond er een "bruinvisberg", opgeslagen in een vrieshuis. In overleg tussen het Ministerie, de Universiteit van Utrecht en Wageningen Marine Research is besloten om deze boventallige bruinvissen met een verkort protocol versneld weg te werken, in een grote massa-sectie. De focus bij deze massa-sectie lag op het verzamelen van de magen voor dieetonderzoek; doodsoorzaken konden veelal niet betrouwbaar worden vastgesteld. Wel werden enkele belangrijke karakteristieken van ieder dier vastgelegd, zoals datum en plaats van de stranding, geslacht en leeftijdscategorie, voedingstoestand en versheid van het kadaver.

Of de magen die via de massa-sectie werden verkregen ook kunnen worden gebruikt in het lopende dieetonderzoek, is in dit rapport uitgezocht. De manier waarop de maag uit een dier wordt genomen heeft uiteraard geen invloed op de maaginhoud, maar het zou wel zo kunnen zijn dat dieren die voor de massasecties zijn bewaard geen goede dwarsdoorsnede vormen van wat bij de meer uitgebreide secties ter tafel komt. Omdat de tijd van het jaar en de leeftijd van de bruinvis een belangrijke invloed hebben op het dieet, kan alleen een zuivere vergelijking worden gemaakt tussen het dieet van twee groepen bruinvissen uit eenzelfde leeftijdscategorie, die gevonden zijn in het hetzelfde seizoen. Omdat het overgrote deel van de massa-sectie-dieren juvenielen waren, zijn dieren van andere leeftijdscategorieën hier verder buiten beschouwing gelaten. Binnen de groep van de juveniele massa-sectie-bruinvissen versus die van de eveneens juveniele dieren die een volledige sectie kregen (de controlegroep) waren er vier jaar/seizoen combinaties met voldoende bruinvissen voor een zinvolle vergelijking van het dieet. Voor drie van deze groepen: januari-maart 2012 (21 massa-sectie-dieren versus 21 controle-dieren); juli-oktober 2012 (42 vs. 43); en maart-mei 2013 (42 vs. 30) werd geen significant verschil in dieet gevonden. Voor september-oktober 2011, met 14 vs. 38 dieren) werd wel een verschil gevonden. In deze periode hadden de massa-sectie-dieren gemiddeld minder kabeljauwachtigen, grondels, zandspieringen en inktvissen gegeten dan de controle dieren en ontbraken een aantal wat zeldzamere prooien helemaal in het dieet van de massa-sectie-dieren, terwijl ze wel voorkwamen in de controlegroep. Wellicht hingen deze observaties samen met het feit dat het aantal beschikbare dieren uit de massa-sectie (14) voor deze groep relatief klein was.

Alles overziende wordt geconcludeerd dat de magen, afkomstig uit de massa-sectie een beeld van het dieet van de bruinvis opleveren dat goed overeen komt het beeld verkregen middels de reguliere secties. Magen uit de massa-sectie zijn dus geschikt voor dieet-onderzoek en het huidige krappe aantal dieren dat regulier wordt onderzocht, zou voor het dieetwerk probleemloos kunnen worden aangevuld met dieren die iets minder vers zijn en die volgens een eenvoudiger pathologie protocol worden onderzocht. 


\section{Summary}

\section{Quick and dirty mass necropsies vs individual, standard necropsies in harbour porpoises: does this affect the monitoring of porpoise diet?}

The greater North Sea provides prime habitat for harbour porpoises. Circa half of the global population lives here and the species enjoys protection under the European Habitat Directive. Parties under the regional Agreement on the Conservation of Small Cetaceans of the Baltic and North Seas (ASCOBANS) have agreed to monitor the population status of the harbour porpoise, its health status, causes of death, and diet. Annual studies on porpoise pathology and diet, conducted on animals stranded dead in The Netherlands, provide the required data on porpoise health, causes of death and diet to the Ministry of Economic Affairs in The Netherlands, the governmental body responsible for nature conservation.

After two years of starting up (2006 and 2007), some 100-200 stranded harbour porpoises went through full necropsy and dietary research annually. Due to a large-scale, southward shift in porpoise distribution in the North Sea, numbers of porpoises (alive and dead) in The Netherlands have increased rapidly. In the years 2011-2013 numbers of stranded animals had risen to more than 800 per year and too many carcasses were collected for research. The numbers overwhelmed the available means to deal with them. The carcasses that could not be processed in the regular monitoring programme were not discarded, but were kept frozen, waiting for a solution to deal with this stock. A solution was found: the stored porpoises were thawed en masse, and given a very quick dissection, aimed mainly at registering place and date of stranding, their gender and age class and their state of decomposition and nutrition. Cause of death was not established but the stomachs were taken out for diet study. The stomach contents were treated in the same way as the stomach contents of animals that went through full necropsy.

If, however, the mass necropsy animals were a biased sample of porpoises as compared to the porpoises that went through full necropsy, one should be careful adding the mass necropsy stomach contents data to the data collected during the standard monitoring. In this study, we check whether the two samples of dietary data are comparable. For such a comparison to be valid, it is important that we compare likes with likes. As the vast majority of the mass necropsy animals were juveniles, only this age class of porpoises was considered. Among these juveniles, we selected animals with prey remains in their stomachs from four sets of two to four consecutive months within the same year, for which we had relatively large numbers of specimens to work with, for both groups of porpoises. The selected groups of animals were checked for differences in stranding locations, decomposition and nutritional status, but such differences were found to be insignificant. Subsequently, the diets between the mass necropsy and control animals were compared for the four selected groups.

14 mass necropsy animals and 38 controls were available for Sep-Oct 2011; 21 for either group for JanMar 2012; 42 and 43 animals, respectively for Jul-Oct 2012; 42 and 30 animals for Mar-May 2013. Only for the first group a significant difference in diet was found between the mass necropsy group and the controls. The animals in the mass necropsy groups had lower reconstructed prey masses of gadoids, gobies, sandeels and squids in their stomachs compared to their control counterparts, and several rarer species that were found as prey incidentally among the controls, were not found in the mass necropsy group. However, only 14 animals were available for the mass necropsy group in this first comparison. The other three selections of porpoises, all with larger numbers of mass necropsy animals, showed no significant differences in diet between the two groups. It may therefore be concluded that the control and mass necropsy animals in 2011-2013 had very similar diets. Therefore, stomachs obtained from excess animals that only go through a minimal necropsy contain dietary information that is valuable, and this information can be added to the data gained from the regular monitoring work on porpoise diet. 


\section{Inleiding}

\subsection{Massa-secties op "boventallige" bruinvissen}

De bruinvis Phocoena phocoena (Linnaeus, 1758), is na een periode van enkele decennia waarin deze kleine walvisachtige zo goed als verdwenen was uit Nederland, tegenwoordig weer talrijk aanwezig in de zuidelijke Noordzee (Camphuysen \& Siemensma 2011; Geelhoed et al. 2014; Gilles et al. 2016;

Hammond et al. 2017). Deze nieuwe status van de soort geeft Nederland de verplichting zich in te zetten voor de instandhouding van bruinvis in Nederlandse wateren. Onder de 'Agreement on the Conservation of Small Cetaceans of the Baltic and North Seas' (ASCOBANS) is in 1994 afgesproken dat er onderzoek zal worden gedaan naar de gezondheidsstatus van de soort, het dieet, en de mate waarin bruinvissen onbedoeld worden bijgevangen in visnetten. Hiertoe financiert het Ministerie van LNV pathologisch en dieet-onderzoek van bruinvissen in Nederland sinds 2006. Aanvankelijk werd geprobeerd om iedere bruinvis, die dood op de Nederlandse kust aanspoelde, voor dit onderzoek te verzamelen (Leopold \& Camphuysen 2006), maar de aantallen aangespoelde dieren namen in de loop der jaren sterk toe, waardoor dit al snel niet meer mogelijk was. In de jaren 2011-2013 strandden er dermate veel dieren (Figuur 1), en werden er zoveel dode dieren op de stranden voor onderzoek verzameld, dat er een voorraad van enkele honderden dieren ontstond (bewaard in een vrieshuis) waarvoor geen budget was om deze regulier te onderzoeken. Omdat er veel tijd, moeite en geld gestoken was in het verzamelen, registreren en bewaren van deze dode bruinvissen, is er aan het ministerie extra budget gevraagd om deze voorraad, van honderden bruinvissen versneld weg te werken. Om deze dieren met "normale" secties te behandelen zou een zeer groot budget nodig geweest zijn. De Universiteit van Utrecht heeft daarom een protocol opgesteld voor een massa-sectie, waarbij alleen de belangrijkste gegevens voor het dieet-onderzoek werden verzameld; de doodsoorzaak van deze dieren kon in de meeste gevallen niet worden vastgesteld.

De nadruk voor het onderzoek aan de massa-sectie-dieren lag dus op hun dieet en een belangrijke vraag hierbij was, of het dieet van deze massa-sectie-dieren te vergelijken is met dat van dieren die een reguliere sectie hebben ondergaan. In dat geval kunnen de data, verkregen uit de massa-sectie, worden toegevoegd aan de data uit het reguliere dieetonderzoek dat loopt sinds 2006 (Leopold \& Camphuysen 2006). Het onderzoek in 2006 en in 2007 werd incidenteel gefinancierd door het Ministerie van LNV. Dit leidde tot een meer structureel onderzoeksproject, dat liep van 2008 tot 2013, waarbij de aantallen verzamelde dieren dus sterk opliepen. Dit resulteerde in 2014 in een "bezinningsjaar" ( 30 secties, in afwachting van een vervolgproject), en 2015 in een kortdurend interim project met de focus op verse dieren, onder de aanname dat versheid voor het dieetwerk niet zou uitmaken, terwijl de opbrengst van het pathologiewerk (per dier) zou toenemen. Vóór 2014 werden dieren voor onderzoek verzameld zonder dat daarbij rekening gehouden werd met de versheid van de kadavers. Vanaf 2014 werden vooral nog verse dieren onderzocht en werden bovendien per jaar minder dieren onderzocht. Een dergelijke trendbreuk in het onderzoeksprotocol heeft het risico in zich dat er ook een trendbreuk in de resultaten ontstaat, in dit geval zowel ten aanzien van de verdeling van de doodsoorzaken (Begeman et al. 2013) als ten aanzien van dieet (Leopold 2015).

Voor het nieuwe onderzoeksprotocol, gebaseerd op minder, en versere dieren werd ingeschat, dat er uit het "aanbod" van dieren die in Nederland stranden, jaarlijks ongeveer 50 verse dieren verzameld zouden kunnen worden en dit aantal werd als norm bepaald. In 2016 werd het onderzoek aan pathologie van bruinvissen toegevoegd aan de Wettelijke Onderzoekstaken (WOT) van het Rijk, waardoor dit werk structureel wordt gefinancierd. Doordat jaarlijks 50 dieren onderzocht, worden de kosten van het onderzoek beperkt. De vraag hierbij is wel, of het aantal van 50 voldoende is voor een goede monitoring van doodsoorzaken en dieet, zeker als we in ogenschouw nemen dat die 50 bruinvissen onderling nog 
verschillen in parameters als leeftijd, conditie, sekse, seizoen van stranden, etc. Mogelijk geven de dieetdata van de massa-sectie (op de boventallig verzamelde en diepgevroren bewaarde bruinvissen) ook een antwoord op de vraag of het aantal onderzochte dieren zonder bezwaar (in termen van dieet) kan worden uitgebreid door meer, en dus gemiddeld minder verse dieren te verzamelen. Deze hoeven dan uiteraard niet eerst in een vrieshuis te worden opgeslagen voor een latere massa-sectie, maar zouden bij het lopende onderzoek kunnen worden meegenomen. Een groter aantal onderzochte dieren zou niet alleen voor dieet-onderzoek een meerwaarde hebben, maar bijvoorbeeld ook voor het bepalen van de incidentie van makkelijk waarneembare doodsoorzaken, zoals (duidelijke) gevallen van bijvangst of predatie door grijze zeehonden.

In dit rapport wordt de vraag onderzocht, of de maaginhoud van dieren die alleen een snelle (massa) sectie hebben ondergaan, te vergelijken is met de maaginhoud van dieren die een volledige (standaard) sectie kregen. Dit is een voorwaarde om eventueel in de toekomst dieren uit massa-secties bij de lopende studie van dieet te betrekken. Om deze vraag te onderzoeken is het dieet van beide groepen dieren vergeleken.

\subsection{De bruinvis}

In de Noordzee en aangrenzende wateren leven circa 345000 bruinvissen van de totale geschatte populatie van 470000 bruinvissen in Europa (Hammond et al. 2017). Wereldwijd is er een populatie van ongeveer 700000 individuen (Bjorge \& Tolley 2008; Jefferson et al. 2015). De bruinvis is met afstand de meest talrijke walvisachtige in de Noordzee en ook de soort die het meest dood aanspoelt in Nederland (Figuur 1). Zijn aantallen in de Noordzee lijken de afgelopen decennia stabiel; wel was er een verschuiving in het zwaartepunt van voorkomen naar de zuidelijke Noordzee. Met steeds meer bruinvissen in Nederlandse wateren, spoelden er hier jaarlijks ook steeds meer bruinvissen dood aan op de kust. Tussen 2000-2007 werden er in Nederland 1846 strandingen gemeld en tussen 2008-2014 was dit aantal opgelopen tot 4346

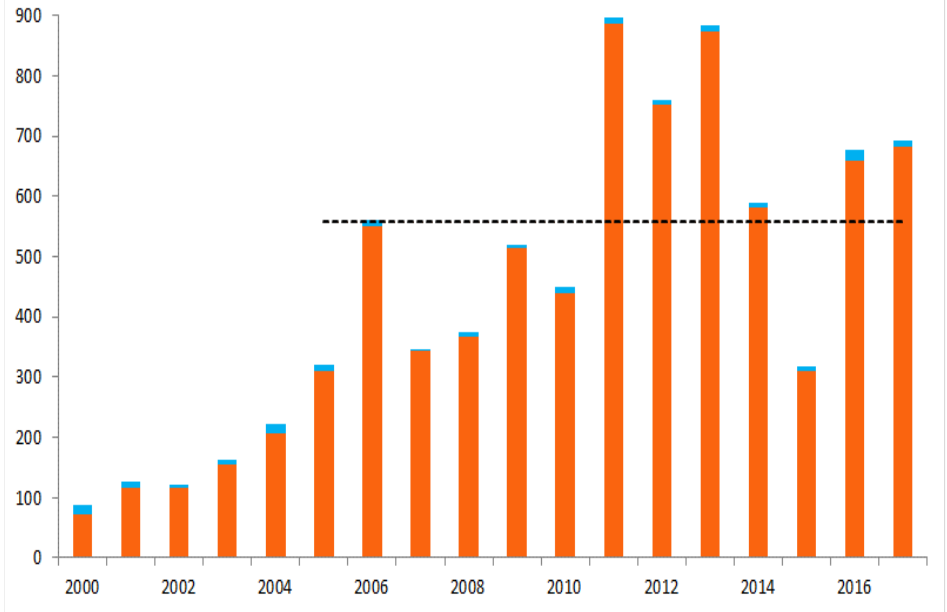

Figuur 1 Aantal strandingen van bruinvissen (oranje) en andere walvisachtigen (blauw) per jaar in Nederland. De stippellijn geeft het gemiddelde weer over de periode 2005-2017. (www.walvistrandingen.nl). (Keijl et al. 2016).

De bruinvis is een van de kleinste walvisachtigen ter wereld (Wilson \& Mittermeier 2014). Mannelijke dieren worden maximaal $180 \mathrm{~cm}$ lang en 61 kg zwaar. Vrouwelijke dieren kunnen $190 \mathrm{~cm}$ lang worden en $76 \mathrm{~kg}$ zwaar (WDC, z.d; J efferson et al. 2015). Bruinvissen leven gemiddeld korter dan de meeste andere walvisachtigen, ze worden vaak niet ouder dan 10 jaar, enkele bereiken een leeftijd van 24 jaar (J efferson et al. 2015).

Bruinvissen bewonen de noordelijke gematigde en subarctische zeeën (Figuur 2). Ze worden meestal aangetroffen in wateren die minder dan 200 meter diep zijn (Hammond et al. 2008; Fontaine et al. 2010; NOAA Fisheries 2014; Jefferson et al. 2015) en leven meestal solitair of in kleine groepen.

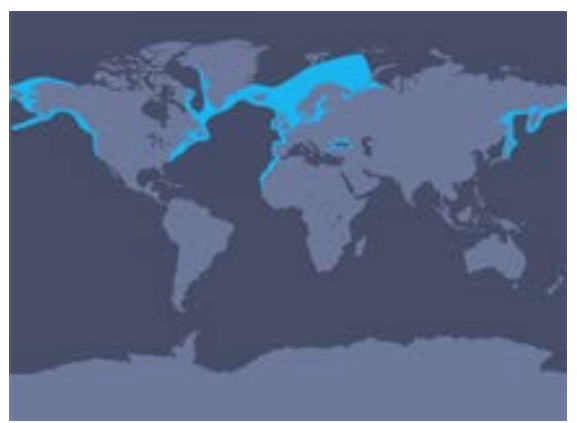

Figuur 2 Bruinvis verspreidingskaart (WDC, z.d.) 


\subsubsection{Dieet}

Omdat de bruinvis zo klein is vergelijking met andere walvisachtigen biedt dit bijzondere mogelijkheden voor deze soort. Bruinvissen hebben, vanwege hun geringe lichaamsomvang, de mogelijkheid om in gebieden te leven waar de meeste andere walvisachtige niet kunnen komen. De zee bevat meer kleinere vissen dan grotere, waardoor voor predatoren van kleine vis er relatief veel voedsel beschikbaar is. Deze factoren zijn mogelijk een verklaring voor de grote aantallen bruinvissen in de Noordzee (Hammond et al. 2002, 2013; Leopold 2015a). Om te kunnen overleven heeft de bruinvis een groot aanbod nodig van kleinere vissen zoals haring Clupea harengus, sprot Sprattus sprattus en grondels Gobiidae (Leopold 2015a). Bruinvissen hebben een snel metabolisme waardoor de dieren min of meer voortdurend moeten blijven eten (Read \& Hohn 1995; Spitz et al. 2012; Leopold 2015a; Wisniewska et al. 2016; Hoekendijk et al. 2017).

\subsubsection{Vijanden}

Door zijn geringe grootte is de bruinvis kwetsbaar voor predatie, door grote haaien zoals de witte haai Carcharodon carcharias (Arnold 1972; Long \& Jones 1996; De Maddalena \& Heim 2012), de orka Orcinus orca (Saulits et al. 2000; Morisaka \& Conner 2007; Dahlheim \& White 2010; Williams et al. 2014) en de grijze zeehond (Vodden 1995; Haelters et al. 2012, 2015; Bouveroux et al. 2014; van Bleijswijk et al. 2014; Jauniaux et al. 2014; Leopold et al. 2015; Stringell et al. 2015). Ook vormt de mens een bedreiging voor de bruinvis. Netten van vissers zijn obstakels in de leefomgeving van de bruinvis. Zij raken verstrikt in deze netten en stikken (J efferson et al. 2015). In Europa sterven jaarlijks duizenden bruinvissen door ongewilde bijvangst in warnetten (Read 1999; Vinther 1999; Stenson 2003; Vinther \& Larsen 2004; Bjørge et al. 2013).

\subsection{Dieet-onderzoek}

Om te begrijpen wat een bruinvis eet en hoe een bruinvis deel uit maakt van het marine ecosysteem zijn er veel dieetstudies gedaan. De belangrijkste prooisoorten die gevonden zijn in Europese en Amerikaanse studies zijn haringachtigen, kabeljauwachtigen, grondels en zandspieringen (Recchia \& Read 1988; Vinther 1999; Börjesson et al. 2003; Santos \& Pierce 2003; Leopold 2015a). Toch worden er ook andere soorten gegeten door de bruinvissen in de noordelijke Atlantische Oceaan. Deels heeft dit met het lokale prooiaanbod te maken: zo wordt bijvoorbeeld in Noorwegen veel lodde Mallotus villosus gegeten (Aarefjord et al. 1995). Deels heeft dit wellicht te maken met lokale "gewoontes": zo eten bruinvissen in Duitsland opvallend veel platvis (iets dat overigens vaak fataal afloopt voor de bruinvis: Roller et al. 2017). Bruinvissen eten niet alleen vis: ook inktvissen, kreeftachtigen en borstelwormen staan op het menu (Martin 1996; Santos 1998; Santos \& Pierce 2003; Schelling et al. 2014). In de Nederlandse wateren zoals de Noordzee of Waddenzee worden voornamelijk magere prooien (prooien met een lage calorische waarde( gegeten, zoals grondels, wijting en kabeljauw (Leopold 2015a). Bij veel dieetonderzoeken zijn prooidieren geïdentificeerd op basis van de otolieten (gehoorsteentjes) en andere harde delen (kaken \& graten)(Santos \& Pierce 2003; Schelling et al. 2014; Leopold 2015a). Deze methode is ook gebruikt bij deze dieetstudie. 


\section{Opdracht}

\subsection{Hypothese secties}

Veel van de dieren die in 2011-2013 strandden, waren in een vergevorderd stadium van decompositie (rot). Onderzoek aan de (maaginhoud van) inmiddels honderden dieren heeft geleerd dat rotte dieren die een reguliere sectie ondergingen, geen wezenlijk ander dieet hadden dan verse dieren (Leopold $2015 a$ ). Verse dieren zijn voor het pathologisch onderzoek echter het meest waardevol. Rotte dieren in de categorie "meer van hetzelfde" kunnen dus een lage prioriteit krijgen. Hetzelfde geldt voor verse juveniele dieren, omdat er van deze categorie relatief veel aanspoelen in Nederland en er voor deze groep dus al veel data beschikbaar zijn.

Van prioritair belang voor reguliere secties zijn dieren die:

1. Aanspoelden in delen van Nederland waar tot nu toe nog maar weinig dieren konden worden geborgen en onderzocht, of die om andere redenen van speciaal lokaal belang zijn: de oostelijke Waddeneilanden, de Waddenzee, de Eems en de Ooster- en Westerschelde (en zeer zeldzame gevallen uit binnenwateren, inclusief de Grevelingen);

2. Zeer jong zijn. Deze kunnen worden gebruikt om na te gaan wanneer jonge dieren starten met het eten van vast voedsel.

3. Adult zijn. Omdat er nog relatief weinig volwassen dieren zij onderzocht.

4. Aanspoelen tijdens incidenten. Te denken valt aan lokale of landelijke massastrandingen of dieren met een opvallend ziektebeeld (uitwendig vast te stellen); duidelijke kenmerken van bijvangst (idem) of verwondingen (idem).

In 2016 is door het Ministerie van LNV de keuze gemaakt om vooral dieren, die in relatief verse staat aanspoelen, te verzamelen voor secties en voor het dieet-onderzoek. In eerdere jaren werden echter niet geselecteerd op versheid en werd dus in dit opzicht een bredere doorsnede van de aangespoelde bruinvissen bemonsterd. Ook onder de boventallige dieren die in het vrieshuis werden opgeslagen was aanvankelijk een brede doorsnede te vinden van dieren waar het gaat om versheid, locatie en leeftijd. Voorafgaand aan de massa-secties zijn echter bepaalde dieren uit de voorraad gehaald die van bijzonder belang leken (zoals de grote, "adulte" dieren). Verwacht wordt echter, dat de dieren die op basis van seizoen van aanspoelen en van pathologie niet verschillen, er geen tot nauwelijks verschil te vinden is tussen de massa-sectie-groep en de reguliere groep (controlegroep genoemd in dit onderzoek).

\subsection{Hypothese maagonderzoek}

Om een zuivere vergelijking te kunnen maken tussen het dieet van dieren uit de massa-sectie-groep en uit de controlegroep, moeten de twee groepen in overige kenmerken zoveel mogelijk overeenkomen. Voor dieet belangrijke kenmerken (Leopold 2015a) zijn: jaar, seizoen, strandingslocatie, leeftijd, en voedingstoestand (NCC). Verwacht wordt dat, als gecorrigeerd wordt voor de belangrijkste factoren, er geen verschil te zien is in het dieet van de massa-sectie-bruinvissen en de controlegroep-bruinvissen: dit is de nulhypothese voor dit onderzoek. Een impliciete aanname bij deze nulhypothese is, dat dieren die in verregaande staat van ontbinding aanspoelen niet afkomstig zijn uit andere delen van de Noordzee dan versere dieren, maar dat ze enkel langer in het water hebben gelegen voordat ze aanspoelden en dat ze daarom hetzelfde dieet hebben als versere bruinvissen). 


\section{Methode}

\subsection{Secties}

De complete groep in het vrieshuis bewaarde bruinvissen bestond uit 283 dieren. Hieronder waren verse en rotte neonaten, juveniele en adulte bruinvissen. Er zijn ongeveer 35 verse volwassen dieren aangetroffen in het vrieshuis. Op deze verse volwassen dieren is een volledige sectie uitgevoerd, conform Begeman et al. (2013) omdat over deze leeftijdsgroep nog relatief weinig informatie voorhanden was. Deze volwassen dieren zijn dus onttrokken aan de massa-sectie-groep. Voor de 248 overige dieren werd een versnelde procedure gebruikt. Hierbij werd alleen de strandingsdatum, strandingslocatie, leeftijd, geslacht, gewicht, lengte, DCC (decomposition condition code: mate van decompositie), NCC (nutritional condition code: de voedingstoestand) geregistreerd. De DCC werd bepaald volgens een vijf-punt-schaal, van erg vers (1) tot erg oude karkassen (5). De NCC werd bepaald volgens een zes-punt schaal, van 1 (erg vet) tot 6 (extreem mager). Deze methode is ontwikkeld door Kuiken \& Garcia Hartmann (1992). Ook werden de magen van deze dieren verzameld voor het dieet-onderzoek. Voor de massa-sectie is er een snijweek georganiseerd waarin alle dieren zijn 'weggesneden' met behulp van een grote ploeg vrijwilligers, waaronder enkele buitenlandse veterinair pathologen, en medewerkers van de faculteit diergeneeskunde in Utrecht en van WMR (voormalige IMARES).

\subsection{Data-exploratie}

Voorafgaande aan de analyse is er eerst een data-exploratie uitgevoerd om te bekijken welke gegevens er gebruikt kunnen voor de dieetanalyse. Binnen de twee groepen (massa-sectie en controle) die met elkaar worden vergeleken, is er als eerste gekeken naar de verschillen op jaarbasis. In de massa-sectiegroep zitten dieren die gestrand zijn in de jaren 2009, 2011, 2012 en 2013. De massa-sectie-groep bevatte slechts één dier uit 2009 en dit jaar is daarom uitgesloten van de analyse. De dieren uit de overige jaren werden tegenover elkaar gezet (Figuur 3). De aantallen in beide groepen zijn vergelijkbaar voor 2012 en 2013, maar voor 2011 zijn er relatief weinig dieren in de massa-sectie-groep. De bruinvissen die zijn geselecteerd voor de vergelijkende dieet-analyse worden in paragraaf 3.2.8 besproken.

\subsubsection{Jaarlijks/ maandelijks aantal magen}

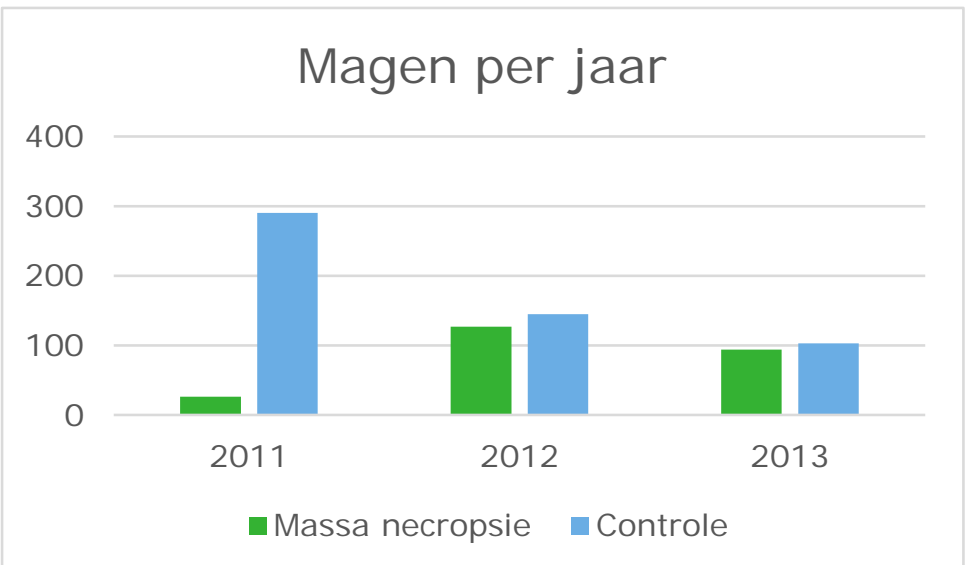

Figuur 3 Vergelijking massa-sectie- met controlegroep-magen per jaar. (massa-sectie: 247 magen, controle: 538 magen) 
Dit is een eerste indicatie van de data die beschikbaar zijn. Om een meer gedetailleerd beeld te krijgen van de dataset zijn de jaren opgedeeld in maanden.

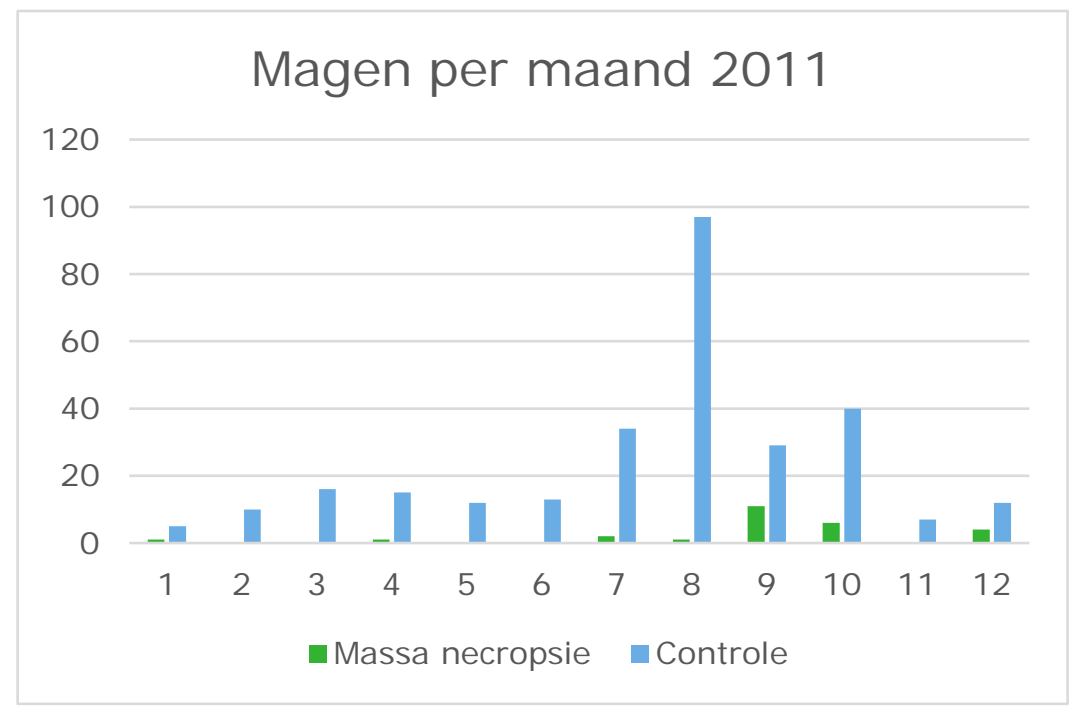

Figuur 4 Vergelijking massa-sectie met controlegroep per maand in 2011. (massa-sectie: 26 magen, controle: 290 magen)

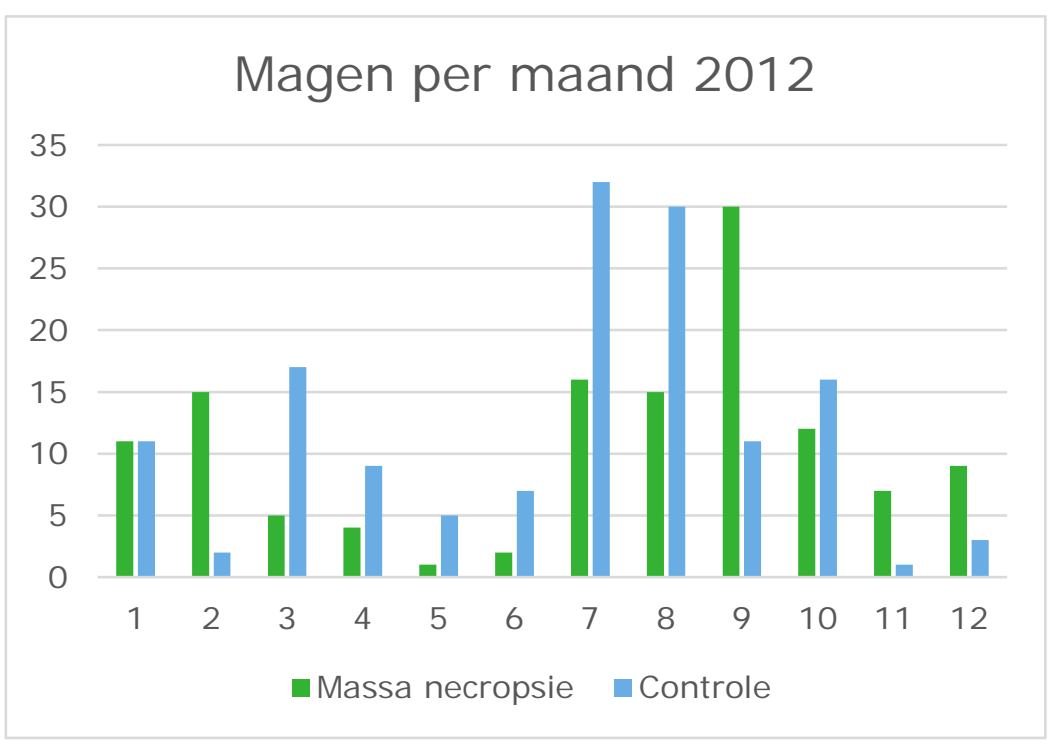

Figuur 5 Vergelijking massa-sectie met controlegroep per maand in 2012. (Massa-sectie: 127 magen, controle: 145 magen) 


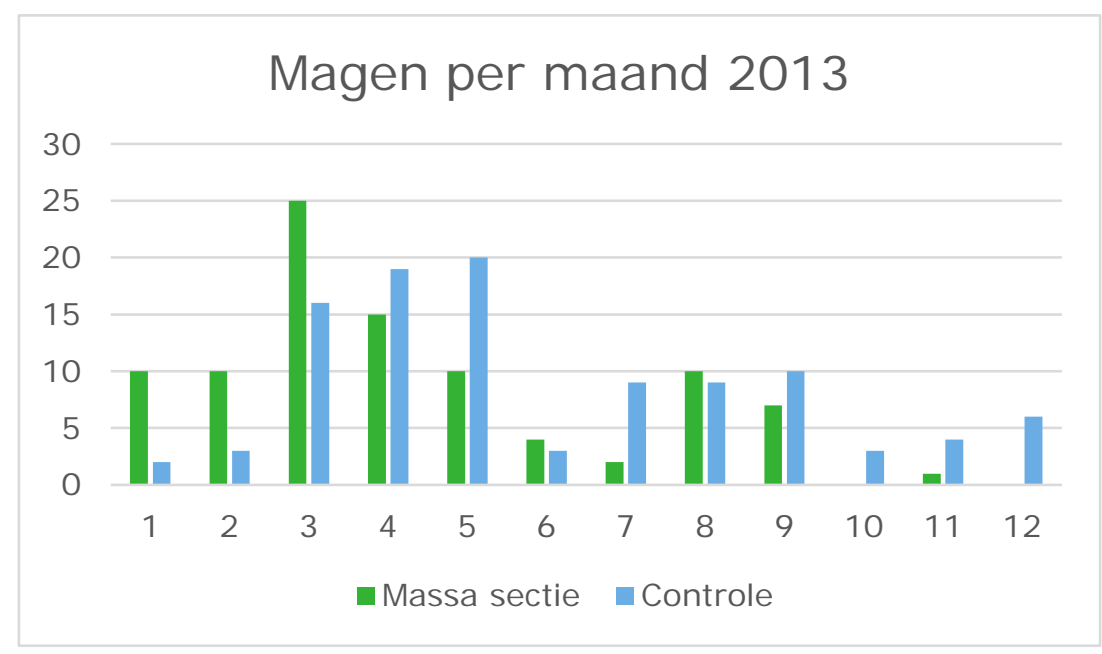

Figuur 6 Vergelijking massa-sectie- met controlegroep per maand in 2013. (Massa-sectie: 94 magen, controle: 103 magen)

In het jaar 2011 (figuur 4) zijn de meeste magen uit de massa-sectie-groep afkomstig uit de maanden september, oktober en december. Er zijn slechts enkele magen aanwezig uit de maanden januari, april en juli. Voor de overige maanden is geen enkele maag beschikbaar.

Voor het jaar 2012 geldt (figuur 5) dat er opvallende uitschieters in aantallen per maand zijn. In de maanden juli en augustus zijn er in de controlegroep meer magen aanwezig dan in de massa-sectiegroep, in de maand september is het omgekeerde het geval. In de maanden maart tot juni zijn er meer controledieren dan massa-sectie-dieren aanwezig.

In 2013 (figuur 6) zijn er in de eerste vier maanden van het jaar relatief veel dieren in de massa-sectiegroep. Aan het eind van het jaar zijn er juist meer dieren in de controlegroep.

Binnen de hele groep van beschikbare magen is gezocht naar groepen van aaneensluitende maanden (binnen een jaar) waarin zowel in de massa-sectie-groep als in de controlegroep relatief veel magen beschikbaar zijn voor onderzoek (tabel 1). In 2011 is dit alleen het geval voor september en oktober. Voor het jaar 2012 kunnen de twee groepen worden vergeleken: voor de maanden januari, februari en maart, en voor juli, augustus, september en oktober. Voor 2013 worden ook twee perioden geselecteerd: de maanden maart, april en mei en de maanden augustus en september. Wat opvalt is dat de jaren 2012 en 2013 twee duidelijk pieken in aantallen te zien zijn; in de winter- en zomermaanden of het voorjaaren de zomermaanden. In 2011 was er alleen een najaarspiek.

Tabel 1 Magen per jaar en maand. Selecties van de vergelijkingen tussen massa-sectie en controle. Gearceerde kolommen zijn de selecties met de grotere aantallen magen.

\begin{tabular}{|c|c|c|c|c|c|c|}
\hline & \multicolumn{2}{|c|}{2011} & \multicolumn{2}{|c|}{2012} & \multicolumn{2}{|c|}{2013} \\
\hline Maand & $\begin{array}{l}\text { Massa- } \\
\text { sectie }\end{array}$ & Controle & $\begin{array}{l}\text { Massa- } \\
\text { sectie }\end{array}$ & Controle & $\begin{array}{l}\text { Massa- } \\
\text { sectie }\end{array}$ & Controle \\
\hline 1 & 1 & 5 & 11 & 11 & 10 & 2 \\
\hline 2 & - & 10 & 15 & 2 & 10 & 3 \\
\hline 3 & - & 16 & 5 & 17 & 25 & 16 \\
\hline 4 & 1 & 15 & 4 & 9 & 15 & 19 \\
\hline 5 & - & 12 & 1 & 5 & 10 & 20 \\
\hline 6 & - & 13 & 2 & 7 & 4 & 3 \\
\hline 7 & 2 & 34 & 16 & 32 & 2 & 8 \\
\hline 8 & 1 & 97 & 15 & 30 & 10 & 9 \\
\hline 9 & 11 & 29 & 30 & 11 & 7 & 10 \\
\hline 10 & 7 & 40 & 12 & 16 & - & 3 \\
\hline 11 & - & 7 & 7 & 1 & 1 & 4 \\
\hline 12 & 4 & 12 & 9 & 3 & - & 6 \\
\hline
\end{tabular}


In tabel 1 zijn zowel gevulde als de lege magen opgenomen. Lege magen vallen echter af (niet geschikt voor dieet-onderzoek). Verdere selecties betreffen de verschillende leeftijdscategorieën, geslachten, voedingstoestanden en decompositie stadia.

\subsubsection{Geslachten}

Tabel 2 Percentages vrouw/ man/ onbekend. Aantal magen massa-sectie: 247, aantal magen controlegroep: 538.

\begin{tabular}{|c|c|c|c|c|c|}
\hline $\begin{array}{l}\% \text { (alle } \\
\text { dieren) }\end{array}$ & Vrouw-\% & Man-\% & N- vrouw & $\mathrm{N}-\mathrm{man}$ & Onbekend \\
\hline Massa-sectie & 39.8 & 60.2 & 97 & 147 & 1.2 \\
\hline Controle & 46.1 & 53.9 & 245 & 287 & 1.1 \\
\hline \multicolumn{6}{|l|}{2011} \\
\hline Massa-sectie & 30.8 & 69.2 & 8 & 18 & 0.0 \\
\hline Controle & 45.5 & 54.5 & 130 & 156 & 1.4 \\
\hline \multicolumn{6}{|l|}{2012} \\
\hline Massa-sectie & 41.6 & 58.4 & 52 & 73 & 1.6 \\
\hline Controle & 49.8 & 50.2 & 139 & 140 & 1.4 \\
\hline \multicolumn{6}{|l|}{2013} \\
\hline Massa-sectie & 39.8 & 60.2 & 37 & 56 & 1.1 \\
\hline Controle & 46.6 & 53.4 & 48 & 55 & 0.0 \\
\hline
\end{tabular}

Over het algemeen komen de percentages man/vrouw tussen de twee bruinvisgroepen goed overeen (tabel 2). Wel zijn er iets meer mannelijke dieren in massa-sectie-groep dan in de controlegroep. Omdat het geslacht van de bruinvis slechts van zeer geringe invloed is op het dieet (Leopold 2015a), en omdat de verschillen tussen de beide groepen (massa-sectie en controle) hier klein zijn, is met geslacht verder geen rekening gehouden.

\subsubsection{Leeftijden}

Tabel 3 Percentages leeftijden totaal en jaarlijks. Aantal dieren massa-sectie: 247, aantal dieren controlegroep: 538.

\begin{tabular}{|c|c|c|c|c|c|c|c|}
\hline$\%$ (alle dieren) & Adult & Juveniel & Neonaat & N- Adult & $\mathrm{N}$-juveniel & $\mathrm{N}$-neonaat & Onbekend \\
\hline Massa-sectie & 13.4 & 78.9 & 7.7 & 33 & 195 & 19 & 0.0 \\
\hline Controle & 23.6 & 65.8 & 10.7 & 126 & 352 & 57 & 0.6 \\
\hline \multicolumn{8}{|l|}{2011} \\
\hline Massa-sectie & 11.5 & 80.8 & 7.7 & 3 & 21 & 2 & 0.0 \\
\hline Controle & 18.0 & 69.6 & 12.5 & 52 & 201 & 36 & 0.3 \\
\hline \multicolumn{8}{|l|}{2012} \\
\hline Massa-sectie & 18.1 & 75.6 & 6.3 & 23 & 96 & 8 & 0.0 \\
\hline Controle & 19.6 & 74.1 & 6.3 & 28 & 106 & 9 & 1.4 \\
\hline \multicolumn{8}{|l|}{2013} \\
\hline Massa-sectie & 7.4 & 83.0 & 9.6 & 7 & 78 & 9 & 0.0 \\
\hline Controle & 44.7 & 43.7 & 11.7 & 46 & 45 & 12 & 0.0 \\
\hline
\end{tabular}

In tabel 3 zijn de aantallen en percentages weergegeven van de leeftijdscategorieën per bruinvisgroep per jaar. In alle jaren waren de meeste dieren juveniel, zowel in de massa-sectie groep als in de controlegroep. Over het algemeen zijn er minder adulte dieren in de massa-sectie-groep. Dit komt doordat de meeste adulte bruinvissen al eerder uit de massa-sectie-groep waren gehaald, voor volledige necropsies. Leeftijd is sterk medebepalend voor het dieet en om deze reden worden in de analyses bruinvissen van verschillende leeftijden niet bij elkaar genomen. 


\subsubsection{NCC (Voedingstoestand)}

Tabel 4 Verschillen in voedingstoestanden totaal en per jaar. NCC; 1: Erg goede voedingstoestand, 2: goede voedingstoestand, 3: normale voedingstoestand, 4: slechte voedingstoestand, 5: erg slechte voedingstoestand, 6: extreem slechte voedingstoestand

\begin{tabular}{|c|c|c|c|c|c|}
\hline $\mathrm{NCC}$ & $\mathrm{N}$ & gem. & Stdev. & $\mathrm{T}, \mathrm{df}$ & Sign. \\
\hline Massa-sectie & 199 & 3.7 & 1.61 & \multirow{2}{*}{$\begin{array}{l}0.805, \\
585\end{array}$} & \multirow[t]{2}{*}{$P>0.1$} \\
\hline Controle & 388 & 3.59 & 1.48 & & \\
\hline \multicolumn{6}{|l|}{ NCC: 2011} \\
\hline Massa-sectie & 12 & 4.58 & 1.62 & \multirow{2}{*}{$\begin{array}{l}1.927 \\
242 \\
\end{array}$} & \multirow[t]{2}{*}{$P<0.05$} \\
\hline Controle & 232 & 3.66 & 1.47 & & \\
\hline \multicolumn{6}{|l|}{ NCC: 2012} \\
\hline Massa-sectie & 98 & 3.94 & 1.68 & \multirow{2}{*}{$\begin{array}{l}1.452, \\
162 \\
\end{array}$} & \multirow[t]{2}{*}{$P>0.1$} \\
\hline Controle & 66 & 3.6 & 1.31 & & \\
\hline \multicolumn{6}{|l|}{ NCC: 2013} \\
\hline Massa-sectie & 89 & 3.31 & 1.45 & \multirow{2}{*}{$\begin{array}{l}0.348, \\
177\end{array}$} & \multirow[t]{2}{*}{$P>0.1$} \\
\hline Controle & 90 & 3.39 & 1.62 & & \\
\hline
\end{tabular}

De NCC-code geeft de voedingstoestand van de bruinvis weer, waarbij de schaal loopt van 1 (erg goede voedingstoestand) tot 6 (extreem slechte voedingstoestand). Dus hoe magerder de bruinvis hoe hoger de NCC-code. Hoewel de NCC-code een continue variabele waarde is en niet een ordinaal getal, mag volgens Leopold (2015a) hierover toch een gemiddelde worden genomen om twee groepen te vergelijken. Vergelijking van de NCC voor alle dieren samen in de massa-sectie- en controlegroepen gaf geen significant verschil (tabel 4). Wordt er gekeken naar de afzonderlijke jaren is er wel een significant verschil, voor het jaar 2011. Voor dit jaar bestaat de massa-sectie-groep echter uit een gering aantal dieren (12). Op grond van deze cijfers is besloten om verder geen rekening te houden met NCC bij de dieetanalyse.

\subsubsection{DCC (Mate van decompositie)}

Tabel 5 Verschillen in decompositie totaal en per jaar. DCC; 1:erg vers, 2: vers, 3: rot, 4: erg rot, 5: overblijfselen.

\begin{tabular}{|c|c|c|c|c|c|}
\hline DCC totaal & $\mathrm{N}$ & gem. & Stdev. & $T, d f$ & Sign. \\
\hline Massa-sectie & 246 & 3.22 & 0.88 & \multirow{2}{*}{$\begin{array}{l}0.551, \\
782 \\
\end{array}$} & \multirow[t]{2}{*}{$P>0.1$} \\
\hline Controle & 538 & 3.26 & 1.07 & & \\
\hline \multicolumn{6}{|l|}{ DCC: 2011} \\
\hline Massa-sectie & 26 & 3.65 & 0.69 & \multirow{2}{*}{\begin{tabular}{|l}
2.338 \\
314 \\
\end{tabular}} & \multirow[t]{2}{*}{$P<0.05$} \\
\hline Controle & 290 & 3.3 & 1.09 & & \\
\hline \multicolumn{6}{|l|}{ DCC: 2012} \\
\hline Massa-sectie & 126 & 3.4 & 0.89 & \multirow{2}{*}{$\begin{array}{l}0.265 \\
269 \\
\end{array}$} & \multirow[t]{2}{*}{$\mathrm{P}>0.1$} \\
\hline Controle & 145 & 3.43 & 0.97 & & \\
\hline \multicolumn{6}{|l|}{ DCC: 2013} \\
\hline Massa-sectie & 87 & 2.87 & 0.79 & 0.296 & \multirow[t]{2}{*}{$P>0.1$} \\
\hline Controle & 103 & 2.83 & 1.07 & 188 & \\
\hline
\end{tabular}

De DCC-code geeft het stadium van decompositie van de bruinvis weer, waarbij de schaal loopt van 1 (erg vers) tot 5 (alleen overblijfselen). Dus hoe rotter de bruinvis hoe hoger de code. Ervan uitgaande dat DCC ook gezien mag worden als een continue variabele, is hier ook het gemiddelde genomen voor de vergelijking. De vergelijking tussen alle massa-sectie- en controledieren leverde geen significant verschil op (tabel 5). Kijkend naar de afzonderlijke jaren is er alleen een significant verschil te zien voor het jaar 2011. Ook voor DCC zijn er in dit jaar voor de massa-sectie-groep relatief weinig dieren beschikbaar (26). Op grond van deze cijfers, en op grond van het feit dat DCC van weinig invloed is op de samenstelling van het dieet (Leopold 2015a) is besloten om verder geen rekening te houden met DCC bij de dieetanalyse. 


\subsubsection{Doodsoorzaken}

Tabel 6 Percentage doodsoorzaken van gestrande bruinvissen per groep.

\begin{tabular}{|l|r|r|r|r|r|}
\hline$\%$ Doodsoorzaken & Acute dood & Infectie & Verhongering & Onbekend & N-totaal \\
\hline Massa-sectie & 5.3 & 0.4 & 0.0 & 94.3 & 247 \\
\hline Controle & 25.5 & 11.0 & 15.8 & 47.8 & 538 \\
\hline
\end{tabular}

Er zijn verschillende doodsoorzaken onder de gestrande bruinvissen. Deze zijn gecategoriseerd in 4 groepen: Acute dood (grijze zeehond slachtoffer, verdrinking), infectie, verhongering en onbekend. Wat opvalt is dat in de massa-sectie-groep de bruinvissen merendeels een onbekende doodsoorzaak hebben (tabel 6). Dit komt omdat er tijdens de massa-snijsecties vrijwel geen aandacht is besteed aan de pathologie. Alleen direct zichtbare doodsoorzaken (zeehond-slachtoffers en opvallende ziekteverschijnselen) zijn voor een aantal dieren genoteerd. Omdat doodsoorzaken bij de massa-sectiedieren in de meeste gevallen niet zijn genoteerd is besloten om verder geen rekening te houden met de doodsoorzaak bij de dieetanalyse.

\subsubsection{Locaties}

Tabel 7 Locaties van de gestrande bruinvissen per groep. NH: Noord-Holland, TX: Texel, ZH: ZuidHolland, ZW: Zuidwesten (Zeeland en Zuid-Holland ten zuiden Hoek van Holland, met uitzondering van Ooster- en Westerschelde).

\begin{tabular}{|l|r|r|r|r|r|r|r|r|}
\hline Locaties & NH & \multicolumn{1}{l|}{ TX } & \multicolumn{1}{l|}{ ZH } & \multicolumn{1}{l|}{ ZW } & Oosterschelde & Westerschelde & Waddenkust & Waddenzee \\
\hline Massa-sectie & 53 & 46 & 38 & 65 & 4 & 6 & 20 & 14 \\
\hline Controle & 63 & 55 & 141 & 213 & 16 & 11 & 19 & 19 \\
\hline $\begin{array}{l}\% \text { Massa- } \\
\text { sectie }\end{array}$ & 45.7 & 45.5 & 21.2 & 23.4 & 20 & 35.3 & 51.3 & 42.4 \\
\hline
\end{tabular}

Bruinvissen spoelen overal langs de Nederlandse kust aan. Als Nederland wordt opgedeeld in een achttal regio's (tabel 7), blijkt dat over het algemeen de aantallen onderzochte dieren per regio voor de beide groepen redelijk gelijk zijn aan elkaar. Wel is te zien dat in ZW-Nederland (Zuid-Holland tot en met de Westerschelde) meer bruinvissen onderzocht zijn in de controlegroep dan in de massa-sectie-groep. Omdat eventuele verschillen in dieet, samenhangend met regio vooral optreden in Ooster- en Westerschelde (Leopold 2015a, van Dam et al., 2017), en de aantallen onderzochte dieren voor deze wateren relatief gering zijn, is met verschillen in aantallen per regio geen rekening gehouden bij de dieetanalyse.

\subsubsection{Overgebleven magen na de selecties}

Om een zuivere vergelijking te maken tussen de massa-sectie-bruinvissen en de controle-bruinvissen zijn groepen bruinvissen geselecteerd die ten aanzien van de belangrijkste co-variabelen die het dieet mede bepalen, zoveel mogelijk gelijk zijn. Hierboven zijn de verschillende parameters die hiervoor van belang zouden kunnen zijn, beschreven. Omdat het aantal beschikbare magen waarmee gewerkt moet worden niet oneindig groot is, is geselecteerd op de belangrijkste parameters. Uit eerder onderzoek (Leopold 2015a) is al gebleken dat vooral de factoren jaar, seizoen, leeftijd en NCC bepalend zijn voor wat bruinvissen eten. Verschillen in NCC tussen beide groepen waren gering, waardoor deze factor buiten beschouwing kan blijven en de analyse hierboven geeft ook aan dat de factoren geslacht, DCC, doodsoorzaak en strandingslocatie kunnen worden genegeerd. Omdat er slechts weinig volwassen dieren in de massa-sectie-groep aanwezig waren (zie paragraaf 2.2) moesten deze van de analyse worden uitgesloten. Zeer jonge dieren, zogenoemde neonaten, zijn ook uitgesloten omdat ze nog geen resten van vast voedsel in de maag hebben. De analyse richt zich dus op dieren van de tussencategorie: de juvenielen. Bruinvissen die bij sectie geen maag of een lege maag bleken te hebben, zijn ook van verdere analyse uitgesloten. In tabel 8 zijn de aantallen onderzochte bruinvissen weergegeven, per groep (massa-sectie versus controle), per jaar, per maand. Uit dit overzicht blijkt, dat er zinvolle vergelijkingen 
gemaakt kunnen worden tussen de twee groepen, voor een viertal combinaties van jaren en maanden: voor alle andere maand/jaar combinaties zijn er te weinig dieren onderzocht.

Tabel 8 Aantallen onderzochte magen van juveniele bruinvissen per maand en per jaar. Massasectie: 161, controle: 279 magen.

\begin{tabular}{|c|c|c|c|c|c|c|}
\hline Juveniele & \multicolumn{2}{|c|}{2011} & \multicolumn{2}{|c|}{2012} & \multicolumn{2}{|c|}{2013} \\
\hline Maanden & $\begin{array}{l}\text { Massa- } \\
\text { sectie }\end{array}$ & Controle & $\begin{array}{l}\text { Massa- } \\
\text { sectie }\end{array}$ & Controle & $\begin{array}{l}\text { Massa- } \\
\text { sectie }\end{array}$ & Controle \\
\hline 1 & 1 & 5 & 4 & 6 & 9 & 0 \\
\hline 2 & 0 & 6 & 13 & 0 & 9 & 1 \\
\hline 3 & 0 & 13 & 4 & 15 & 22 & 13 \\
\hline 4 & 0 & 10 & 3 & 8 & 12 & 12 \\
\hline 5 & 0 & 8 & 1 & 2 & 8 & 5 \\
\hline 6 & 0 & 2 & 1 & 3 & 1 & 2 \\
\hline 7 & 0 & 11 & 6 & 16 & 1 & 0 \\
\hline 8 & 0 & 57 & 11 & 12 & 4 & 1 \\
\hline 9 & 9 & 15 & 19 & 5 & 1 & 1 \\
\hline 10 & 5 & 23 & 6 & 10 & 0 & 1 \\
\hline 11 & 0 & 3 & 3 & 0 & 1 & 3 \\
\hline 12 & 1 & 7 & 6 & 1 & 0 & 2 \\
\hline
\end{tabular}

In tabel 8 zijn maand/jaar combinaties met relatief veel bruinvissen in beide groepen gearceerd. Deze periodes worden gebruikt voor de dieetanalyse.

Tabel 9 Overgebleven adulte magen na selectie. Massa-sectie: 26, controle: 104 magen. In geen enkele jaar/ maand combinatie waren er voldoende dieren in beide groepen voorhanden voor een zinvolle vergelijking van het dieet.

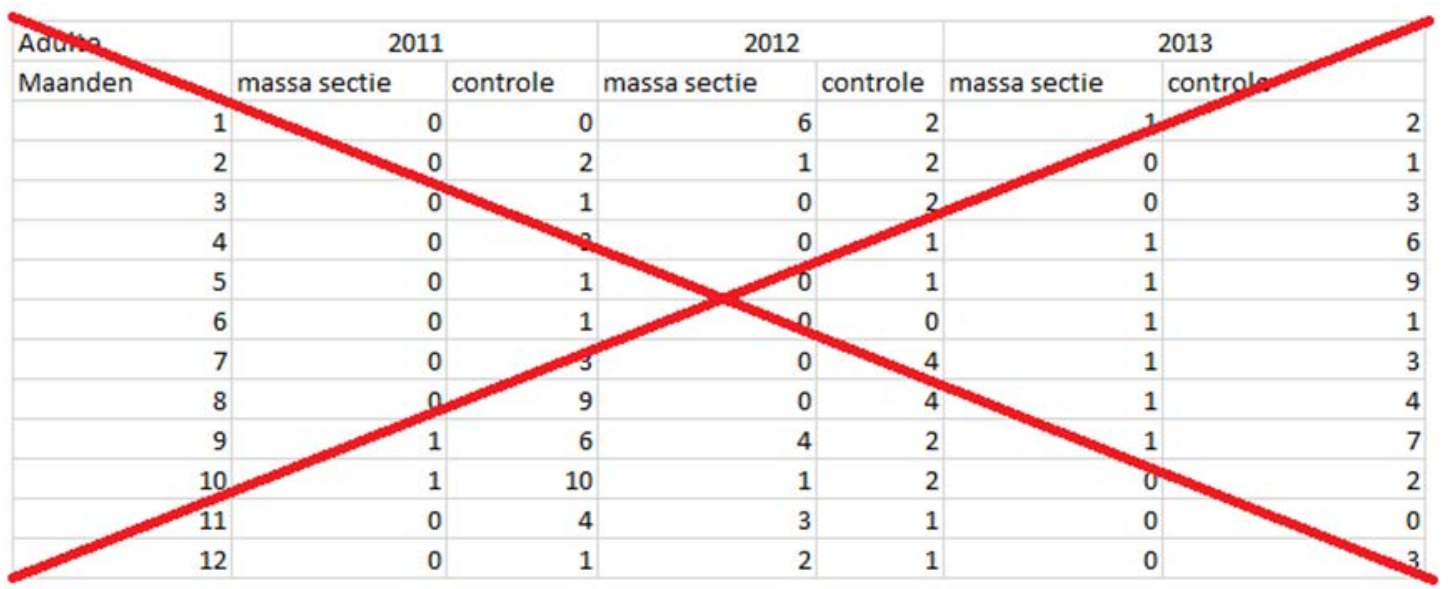

In tabel 9 zijn de overbleven adulte bruinvissen na de selectie uit de jaren 2011-2013 weergeven. Zoals te zien is zijn er steeds te weinig adulte dieren, met name in de massa-sectie-groep, voor een zinvolle analyse. Daarom is ervoor gekozen om alle adulten van verdere analyses uit te sluiten.

Tabel 10 Locaties van de overgebleven bruinvissen, na alle selecties. NH: Noord-Holland, TX: Texel, ZH: Zuid-Holland, ZW: Zuidwesten (Zeeland en Zuid-Holland ten zuiden Hoek van Holland, met uitzondering van Ooster- en Westerschelde).

\begin{tabular}{|l|r|r|r|r|r|r|r|r|}
\hline Locaties & \multicolumn{1}{|c|}{ NH } & \multicolumn{1}{l|}{ TX } & ZH & ZW & Oosterschelde & Westerschelde & Waddenkust & Waddenzee \\
\hline Massa-sectie & 24 & 18 & 20 & 37 & 3 & 3 & 5 & 8 \\
\hline Controle & 13 & 9 & 28 & 67 & 4 & 1 & 2 & 5 \\
\hline$\%$ Massa-sectie & 64.9 & 66.6 & 41.6 & 35.6 & 42.9 & 75 & 71.4 & 61.5 \\
\hline
\end{tabular}


De locaties van de bruinvissen die zijn geselecteerd voor de analyses zijn in tabel 10 weergegeven. De grootste groepen komen nog steeds uit het zuidwesten (ZW) en Zuid-Holland. De overige bruinvissen zijn regelmatig verdeeld over de andere locaties. Er zijn minder dieren beschikbaar uit de Ooster- en Westerschelde en van Waddenkust en Waddenzee. Deze dieren zijn ook van te voren uit de massa-sectie gehaald (zie paragraaf 2.1). Voor de noordelijke helft van Nederland zijn relatief veel dieren in de massasectiegroep beschikbaar.

\subsection{Inventarisatie bruinvismagen}

$\mathrm{Na}$ de massa-sectie zijn alle uitgenomen magen ingevroren bewaard (iedere maag in een apart, gelabelde plastic zak) bij de faculteit pathologie in Utrecht zodat deze later zonder verlies van inhoud konden worden overgebracht naar WMR in Den Helder. Hier is door studenten en vrijwilligers de maaginhoud van bruinvissen uitgezocht volgens de WMR-standaard methode voor dieet-onderzoek (Leopold 2015a). Hierbij wordt er gekeken naar de otolieten (gehoorbeentjes) en andere harde onderdelen van de gegeten vissen, maar ook naar harde delen van andere prooien; bijvoorbeeld wormenkaken, garnalenstaarten en -ogen, kaken en ogen van inktvissen en parasieten van bepaalde vissoorten (Härkönen 1986, Watt et al. 1997, Leopold et al. 2001, WMR referentie materiaal). Bekend is dat wanneer er niet alleen naar otolieten wordt gekeken, maar ook naar de overige onderdelen van de prooien er meer soorten worden waargenomen (Tollit et al. 2004). Prooien worden over het algemeen snel verteerd, maar de harde delen van de prooi blijven langer achter in de maag. Deze onderdelen worden door het maagsap langzamer verteerd maar zullen wel verslijten. Voor deze slijtage wordt gecorrigeerd (conform Leopold 2015a). De otolieten of andere harde onderdelen van de prooien worden met elkaar gepaard wanneer dit mogelijk is en de overgebleven enkele items worden gezien als representanten van aparte prooien. De biomassa's van alle prooien worden berekend aan de hand van de gemeten lengte en/of breedte van de gevonden harde onderdelen (Härkönen 1986, Leopold et al. 2001).

Bruinvissen hebben vier achter elkaar liggende magen; de eerste maag functioneert als opslag en deels voor de vertering met behulp van de verteringsappen die uit de tweede maag komen. In de tweede maag en vierde maag vindt verdere vertering plaats. De derde maag is slechts een kanaal tussen de tweede en vierde maag in. Vaak wordt alleen de inhoud uit de eerste maag gebruikt voor dieet-onderzoek (Leopold $\&$ Camphuysen 2006). Bij dit dieet-onderzoek is er voor gekozen om in alle magen te kijken.

Het verzamelen van de maaginhoud gaat op de volgende wijze. De maag wordt uit de vriezer gehaald om te ontdooien. Wanneer de maag ontdooid is, wordt als eerste maag één in een opvangbak in de lengte opengeknipt en wordt de doorgang gezocht naar maag twee die ook wordt opengeknipt (zie figuur 7)| Maag vier kan via de buitenkant worden opengeknipt. Het hele magencomplex wordt gespoeld in een bekerglas, daarbij wordt eventuele gemorste maaginhoud die opgevangen is in de opvangbak hierbij gevoegd. Het bekerglas wordt vervolgens onder een kraan met langzaam stromend water gezet, waardoor het na enige tijd overstroomt. Lichte resten worden door het overstromende water afgevoerd. Door het bekerglas op een zeef te zetten met een maaswijdte van $1 \mathrm{~mm}$, worden deze resten nog opgevangen ter controle. De otolieten blijven door hun hoge soortelijke gewicht liggen op de bodem van het bekerglas. Mochten er harde, maar lichte onderdelen van inktvissen, wormen, garnalen of andere ongewervelden met de waterstroom meedrijven, dan worden deze opgevangen door de zeef. De zware harde onderdelen verzamelen zich onder in het bekerglas en worden na afgieten in een petrischaal 
overgebracht. Daarna wordt het verzamelde materiaal uitgezocht onder een stereomicroscoop om de prooien te determineren en worden alle onderdelen opgemeten onder de microscoop met behulp van Axiovision software (AxioVs 40 v.4.7\& 4.8). Mocht het niet mogelijk zijn om deze schalen uit te zoeken wegens beperkt zicht (bijvoorbeeld door een erg grote hoeveelheid aan visbotten), dan wordt de inhoud door drie op elkaar gestapelde zeven gespoeld. Hierdoor worden er drie fracties (>1 mm, >500 $\mu \mathrm{m}$, $>355 \mu \mathrm{m}$ ) gecreëerd zodat het uitzoeken wordt vereenvoudigd, zeker wanneer er zich in het materiaal grote aantallen (honderden, of duizenden) kleine otolieten bevinden. Alle prooidieren worden ingevoerd in een speciaal voor dit doel ontworpen databestand, hier worden de vislengtes bepaald op basis van de otolietlengte en -breedte en omgezet in biomassa, volgens regressievergelijkingen in Leopold et al. (2001). Voor ongewervelde wordt dezelfde procedure gebruikt, aan de hand van specifieke harde delen. Op de gevonden aantallen prooien en hun geschatte grootte en massa is de verdere dieetanalyse gebaseerd. De otolieten en overige harde onderdelen van de prooien worden gedroogd en bewaard voor eventuele latere checks op de determinatie.

\subsection{Analyses}

\subsubsection{T-toets}

Voor de vergelijkingen in de data-exploratie voorafgaande aan het onderzoek is de T-Test voor ongepaarde waarnemingen gebruikt. Hierbij worden de gemiddelden voor de twee groepen (massa-sectie en controle), met bijbehorende standaard deviaties en aantallen met elkaar vergeleken. NB: deze toets is ook al eerder gebruikt in dit rapport, voor de data exploratie (hoofdstuk 3.2).

\subsubsection{PERMANOVA}

Met de PERMANOVA-analyse (in Primer versie 7.0.7; Clarke \& Gorley 2015) ('Permutational multivariate analysis of variance') is onderzocht of dieet als geheel verschilt tussen beide groepen. Deze test is een multivariabele analyse en test de nulhypothese (geen verschil) op basis van de afstanden tussen de centroiden, die gelijkwaardig zijn voor alle groepen (Anderson 2001, McArdle \& Anderson 2001). De test houdt rekening met de relatieve aandelen van de diverse prooigroepen (niet: prooisoorten: zie paragraaf 4.1) aan het dieet, en met de relatieve aantallen prooien binnen de verschillende prooigroepen. Op basis van de data-exploratie zijn er vier selecties gemaakt uit de jaren 2011, 2012 en 2013. De selecties vallen uiteen in vier seizoen/jaar combinaties, (paragraaf 3.2.8). Er is daarom vier keer een PERMANOVAanalyse uitgevoerd over de verschillende selecties (tabel 8). Omdat er tussen individuele maaginhouden grote verschillen waren in prooimassa's per prooisoort zijn de gegevens eerst met een $4^{\mathrm{e}}$ machtswortel getransformeerd. Wanneer er voor een bepaalde selectie van dieren een significant verschil in dieet wordt gevonden is dit nader geanalyseerd met een SIMPER-analyse (binnen hetzelfde PERMANOVA pakket). SIMPER berekent de gemiddelde afwijking tussen alle prooigroepen en beoordeelt vervolgens de relatieve ongelijkheid die door elke prooigroep wordt bijgedragen (Clarke \& Gorley 2015) zodat kan worden nagegaan welke prooigroepen het meeste bijdragen aan het gevonden verschil tussen beide groepen. 


\section{Resultaten}

\subsection{Prooigroepen}

In de onderzochte magen van de geselecteerde groepen; massa-sectie en controle, zijn verscheidene prooisoorten waargenomen (Tabel 11). Wellicht waren niet al deze prooien een primaire prooisoort voor de bruinvissen maar waren sommige een secundaire prooi. Een wijting eet bijvoorbeeld een garnaal, de wijting (primaire soort) wordt daarna gegeten door de bruinvis. Resten van de garnaal (secundaire soort) worden ook in de maag van de bruinvis gevonden, maar dat betekent niet dat het een prooi van de bruinvis zelf was. Voor magen met resten van veel wijtingen en weinig garnalen ligt deze keten van gebeurtenissen voor de hand, maar garnalen werden ook wel waargenomen in bruinvismagen zonder de aanwezigheid van wijting of andere vissen die de garnalen gegeten zouden kunnen hebben. De garnaal kan dus ook een primaire prooi zijn. Hetzelfde geldt voor de zagers, kleine inktvissen of kleine vissen. Omdat de voedingswaarde van secundaire prooien ten goede komt aan de apex predator (de bruinvis) en omdat niet altijd kan worden vastgesteld wat primaire en secundaire prooien zijn, worden prooien die zowel primair als secundair kunnen zijn, meegenomen in de dieetanalyse, als waren zij alle primaire prooien. Secundaire prooien waarvan het onwaarschijnlijk is dat ze primaire prooien kunnen zijn, zoals tweekleppig schelpdieren (bivalven) of mariene huisjesslakken (gastropoden), zijn van de analyse uitgesloten.

Omdat sommige numeriek belangrijke prooien vaak niet met zekerheid tot op soort gedetermineerd konden worden (grondels, zandspieringen) zijn alle prooisoorten in groepen ingedeeld: clupeiden (haringachtigen), demersale (bodem bewonende) (rond) vissen, estuariene vissen, gadoiden (kabeljauwachtigen), grondels, pelagische vissen (soorten die hoger in de waterkolom leven), zandspieringen, platvissen en overige vissen, inktvissen, en invertebraten (overige ongewervelden). Onder de clupeiden vallen de haringachtigen haring en sprot. Kabeljauwachtigen, platvissen en grondels zijn alle demersale vissen, maar deze zijn in eigen groepen geplaatst omdat ze de belangrijkste prooigroepen zijn van de bruinvis (Leopold 2015a), dan wel een sterk afwijkende vorm hebben (platvissen). Estuariene vissen zijn de vissen die in brakwater leven, de overgang tussen rivieren en zee. Voorbeelden zijn spiering en grote koornaarvis. Zandspieringen zijn ook in een eigen groep ingedeeld vanwege hun aparte levenswijze: ze komen vaak ingegraven in de bodem (Froese, z.d.) voor en vereisen wellicht speciale foerageertechnieken van de bruinvissen. Daarbij zijn zandspieringen ook belangrijke prooien van bruinvissen in Nederland. Onder de inktvissen vallen alle (dwerg)inktvissen en (dwerg)pijlinktvissen. Onder de (overige) ongewervelden vallen alle andere dieren zonder wervelkolom zoals de kreeftachtigen en zagers. Zeenaalden zijn de enige vissen die onder de groep overige vissen vallen, dit omdat het niet duidelijk is waar het habitat van de zeenaald zich bevindt. Zoals te zien is in de tabel is het niet altijd gelukt om iedere vis tot op soort te determineren maar lukte dit altijd wel tot op familie. Het groeperen van prooisoorten maakt dat er in de analyse minder vaak rekening gehouden moet worden met zeldzame soorten en het voorkomt soortspecifieke determinatiefouten binnen de functionele groepen.

In tabel 8 staan ook twee zoetwatervissen: de blankvoorn en de pos. Deze vissen zijn waarschijnlijk via spuisluizen van het zoet- naar zoutwater naar buiten gespuwd. De blankvoorn en pos zijn daarom ingedeeld in de groep estuariene vissen.

Tabel 11 Gevonden prooisoorten van de bruinvis, gegroepeerd in de verschillende prooigroepen (volgende pagina). Binnen elke prooigroep is een taxonomische volgorde aangehouden volgens Muus et al., 1999 en WoRMS, 2017. !: prooien gedetermineerd aan de hand van het samen voorkomen voor specifieke parasieten en (grote) ooglenzen in de maag. 


\begin{tabular}{|c|c|c|c|c|c|c|}
\hline Prooigroep & NL naam & Engelse naam & Wetenschappelijke naam & $\begin{array}{l}\mathrm{N}- \\
\text { Controle }\end{array}$ & $\begin{array}{l}\mathrm{N}- \\
\text { Massa- } \\
\text { sectie }\end{array}$ & Prooi \\
\hline clupeiden & Haring & Herring & Clupea harengus & 692 & 275 & ja \\
\hline clupeiden & Sprot & Sprat & Sprattus sprattus & 811 & 918 & ja \\
\hline clupeiden & Haring/Sprot & Herring/Sprat & & 2 & 0 & ja \\
\hline demersale vissen & Zeeprik & Sea lamprey & Petromyzon marinus & 0 & 1 & ja \\
\hline demersale vissen & Grauwe poon & Grey gurnard & Eutrigla gurnardus & 0 & 3 & ja \\
\hline demersale vissen & Rode poon & Tub gurnard & Trigla lucerna & 1 & 0 & ja \\
\hline demersale vissen & Gewone zeedonderpad & Bullrout & Myoxocephalus scorpius & 1 & 0 & ja \\
\hline demersale vissen & Harnasmannetje & Hooknose & Agonus cataphractus & 1 & 0 & ja \\
\hline demersale vissen & Puitaal & Eelpout & Zoarces viviparus & 0 & 1 & ja \\
\hline demersale vissen & Botervis & Butterfish & Pholis gunnellus & 1 & 0 & ja \\
\hline demersale vissen & Kleine pieterman & Lesser weaver & Echiichthys vipera & 1 & 0 & ja \\
\hline demersale vissen & Gewone pitvis & Dragonet & Callionymus lyra & 131 & 0 & ja \\
\hline estuariene vissen & Rivierprik & Lampern & Lampetra fluviatilis & 2 & 0 & ja \\
\hline estuariene vissen & Ansjovis & Anchovy & Engraulis encrasicolus & 24 & 0 & ja \\
\hline estuariene vissen & Fint & Twaite shad & Alosa fallax & 1 & 2 & ja \\
\hline estuariene vissen & Spiering & Smelt & Osmerus eperlanus & 1367 & 997 & ja \\
\hline estuariene vissen & Zeeforel & See trout & Salmo trutta & 1 & 0 & ja \\
\hline estuariene vissen & Goudharder & Golden grey mullet & Liza aurata & 1 & 0 & ja \\
\hline estuariene vissen & Grote koornaarvis & Sand smelt & Atherina presbyter & 164 & 15 & ja \\
\hline estuariene vissen & Pos & Ruffe & Gymnocephalus cernuus & 0 & 1 & ja \\
\hline estuariene vissen & Blankvoorn & Roach & Rutilus rutilus & 0 & 1 & ja \\
\hline gadoiden & Kabeljauw & Atlantic cod & Gadus morhua & 137 & 50 & ja \\
\hline gadoiden & Steenbolk & Bib & Trisopterus luscus & 29 & 6 & ja \\
\hline gadoiden & Dwergbolk & Poor cod & Trisopterus minutus & 10 & 4 & ja \\
\hline gadoiden & bolk spec. & Bib/Poor cod & Trisopterus spec. & 37 & 4 & ja \\
\hline gadoiden & Wijting & Whiting & Merlangius merlangus & 731 & 444 & ja \\
\hline gadoiden & Wijting! & Whiting! & Merlangius merlangus & 124 & 48 & ja \\
\hline gadoiden & Koolvis & Saithe & Pollachius virens & 0 & 1 & ja \\
\hline gadoiden & Vijfdradige meun & Five-bearded rockling & Ciliata mustela & 3 & 4 & ja \\
\hline grondels & Zwarte grondel & Black goby & Gobius niger & 19 & 25 & ja \\
\hline grondels & Blonde grondel & Two-spot goby & Gobiusculus flavescens & 292 & 38 & ja \\
\hline grondels & Dikkopje & Sand goby & Pomatoschistus minutus & 55123 & 29079 & ja \\
\hline grondels & Lozano's grondel & Lozano's goby & Pomatoschistus lozanoi & 62 & 307 & ja \\
\hline grondels & Brakwatergrondel & Common goby & Pomatoschistus microps & 880 & 1 & ja \\
\hline grondels & Gevlekte grondel & Painted goby & Pomatoschistus pictus & 392 & 150 & ja \\
\hline grondels & Glasgrondel & Transparent goby & Aphia minuta & 377 & 2306 & ja \\
\hline grondels & grondel spec. & goby spec. & Pomatoschistus spec & 3928 & 0 & ja \\
\hline pelagische vissen & Zeebaars & European seabass & Dicentrarchus labrax & 50 & 72 & ja \\
\hline pelagische vissen & Horsmakreel & Atlantic horse mackerel & Trachurus trachurus & 99 & 33 & ja \\
\hline pelagische vissen & Makreel & Atlantic mackerel & Scomber scombrus & 33 & 1 & ja \\
\hline zandspieringen & Smelt & Greater sandeel & Hyperoplus lanceolatus & 339 & 100 & ja \\
\hline zandspieringen & Noordse zandspiering & Lesser sandeel & Ammodytes marinus & 285 & 5 & ja \\
\hline zandspieringen & Kleine zandspiering & Small sandeel & Ammodytes tobianus & 26 & 0 & ja \\
\hline zandspieringen & zandspiering spec. & sandeel spec. & Ammodytes spec & 4098 & 821 & ja \\
\hline overige vissen & Kleine zeenaald & Lesser pipefish & Syngnathus rostellatus & 193 & 282 & ja \\
\hline overige vissen & Grote zeenaald & Greater pipefish & Syngnathus acus & 2 & 0 & ja \\
\hline platvissen & Tarbot & Turbot & Psetta maxima & 1 & 0 & ja \\
\hline platvissen & Lange schar & Long rough dab & Hippoglossoides platessoides & 2 & 0 & ja \\
\hline platvissen & Schar & Dab & Limanda limanda & 2 & 1 & ja \\
\hline platvissen & Schol & Plaice & Pleuronectes platessa & 3 & 0 & ja \\
\hline platvissen & Bot & Flounder & Platichthys flesus & 0 & 1 & ja \\
\hline platvissen & Tong & Sole & Solea solea & 21 & 1 & ja \\
\hline platvissen & Dwergtong & Solenette & Buglossidium luteum & 2 & 5 & ja \\
\hline inktvissen & Gewone pijlinktvis & European squid & Loligo vulgaris & 2 & 0 & ja \\
\hline inktvissen & Dwergpijlinktvis & European common squid & Alloteuthis subulata & 107 & 117 & ja \\
\hline inktvissen & Gewone zeekat & Common cuttlefish & Sepia officinalis & 8 & 1 & ja \\
\hline inktvissen & Dwerginktvis & Atlantic bobtail squid & Sepiola atlantica & 124 & 123 & ja \\
\hline inktvissen & Rode dwerginktvis & Red bobtail & Sepiola tridens & 2 & 0 & ja \\
\hline inktvissen & Langwerpige dwerginktvis & Common bobtail & Sepietta oweniana & 1 & 0 & ja \\
\hline inktvissen & dwerginktvis spec. & bobtail spec. & Sepiola/Sepietta & 253 & 26 & ja \\
\hline invertebraten & Gewone heremietkreeft & Hermit crab & Pagurus bernhardus & 5 & 0 & nee \\
\hline invertebraten & Callianassa & Sand ghost shrimp & Callianassa tyrrhena & 1 & 0 & nee \\
\hline invertebraten & Strandkrab & Common shore crab & Carcinus maenas & 2 & 0 & nee \\
\hline invertebraten & Gewone zwemkrab & Swimming crab & Liocarcinus holsatus & 1 & 0 & nee \\
\hline invertebraten & Gewimperde zwemkrab & Arch-fronted swimming crab & Liocarcinus navigator & 2 & 0 & nee \\
\hline invertebraten & Nagelkrab & Thumbnail crab & Thia scutellata & 1 & 0 & nee \\
\hline invertebraten & Garnaal & Brown shrimp & Crangon crangon & 289 & 119 & $\mathrm{ja} / \mathrm{nee}$ \\
\hline
\end{tabular}




\begin{tabular}{|c|c|c|c|c|c|c|}
\hline invertebraten & Gewone zeeduizendpoot & Slender ragworm & Nereis pelagica & 10 & 0 & $\mathrm{ja} / \mathrm{nee}$ \\
\hline invertebraten & Zager & King ragworm & Nereis virens & 6 & 7 & $\mathrm{ja} / \mathrm{nee}$ \\
\hline invertebraten & Ambergele zeeduizendpoot & Pileworm & Nereis succinea & 4 & 4 & $\mathrm{ja} / \mathrm{nee}$ \\
\hline invertebraten & Lange zeeduizendpoot & Long ragworm & Eunereis longissima & 66 & 15 & $\mathrm{ja} / \mathrm{nee}$ \\
\hline invertebraten & Wadpier & Lugworm & Arenicula marina & 1 & 0 & nee \\
\hline invertebraten & Amerikaanse zwaardschede & American razorclam & Ensis leei & 0 & 49 & nee \\
\hline invertebraten & Ovale strandschelp & Through shell & Spisula elliptica/solida & 6 & 0 & nee \\
\hline
\end{tabular}




\subsection{Lege magen}

Op een totaal van 247 onderzochte bruinvismagen in de massa-sectie-groep waren 56 magen leeg $(22.7 \%)$. De controlegroep had een totaal aantal van 538 magen waarvan er 139 leeg waren (25.8\%). De verdeling van de lege magen per maand/jaar per groep bruinvissen wordt weergegeven in tabel 12.

Tabel 12 Aantal lege magen per jaar per groep bruinvissen ( $\mathbf{N}$ massa-sectie: 56, $\mathbf{N}$ controle: 139 ).

\begin{tabular}{|r|r|r|r|r|r|r|}
\hline \multicolumn{1}{|c|}{ N- lege magen } & \multicolumn{3}{|c|}{ Massa-sectie } & \multicolumn{3}{|c|}{ Controle } \\
\hline Maand & 2011 & 2012 & 2013 & 2011 & 2012 & 2013 \\
\hline 1 & 0 & 1 & 0 & 0 & 3 & 0 \\
\hline 2 & 0 & 1 & 1 & 2 & 0 & 1 \\
\hline 3 & 0 & 1 & 1 & 2 & 0 & 0 \\
\hline 4 & 1 & 1 & 2 & 0 & 0 & 1 \\
\hline 5 & 0 & 0 & 1 & 3 & 2 & 6 \\
\hline 6 & 0 & 1 & 1 & 10 & 4 & 0 \\
\hline 7 & 2 & 10 & 0 & 18 & 12 & 5 \\
\hline 8 & 1 & 4 & 5 & 29 & 12 & 3 \\
\hline 9 & 1 & 7 & 5 & 7 & 2 & 2 \\
\hline 10 & 0 & 4 & 0 & 5 & 4 & 0 \\
\hline 11 & 0 & 1 & 0 & 0 & 0 & 0 \\
\hline 12 & 3 & 1 & 0 & 4 & 1 & 1 \\
\hline
\end{tabular}

Wat opvalt (tabel 12) is dat in de maanden juni, juli en augustus relatief veel legen magen werden aangetroffen. Dit is te verklaren doordat er in de zomer over het algemeen veel meer strandingen hebben plaatsgevonden dan in andere seizoenen (zie figuur 4,5 en 6). In de zomermaanden eten bruinvissen ook minder dan in de wintermaanden (Leopold 2015a; Kastelein et al. 2018).

\subsubsection{NCC (Voedingstoestand)}

Lege magen kunnen een momentopname zijn in het leven van een bruinvis, maar het is ook denkbaar dat een lege maag indicatief is voor problemen bij het vinden van voedsel. In dat geval zouden lege magen vaker voor moeten komen bij vermagerde bruinvissen. Hoe hoger de NCC-code is hoe erger de bruinvis is vermagerd. Verwacht wordt dat bij een hogere NCC-code meer lege magen worden aangetroffen.

Tabel 13 Percentage codes NCC van lege magen. Massa-sectie: 34 magen, controle: 73 magen. P volgens T-toets.

\begin{tabular}{|c|c|c|c|c|c|c|c|c|c|c|c|}
\hline$\%$ NCC lege magen & 1 & 2 & 3 & 4 & 5 & 6 & Onbekend & $\mathrm{N}-\mathrm{DCC}$ & Avg-DCC & stdev & $\mathrm{P}$ \\
\hline Massa-sectie & 11.8 & 5.9 & 8.8 & 20.6 & 2.9 & 23.5 & 26.5 & 34 & 3.6 & 1.52 & \multirow[t]{2}{*}{$P>0.1$} \\
\hline Controle & 2.7 & 5.5 & 1.4 & 15.1 & 19.2 & 12.3 & 43.8 & 73 & 3.7 & 1.52 & \\
\hline
\end{tabular}

In tabel 13 is te zien dat bij de massa-sectie het aandeel lege magen het hoogst was bij dieren met NCC 4 of 6 . Bij de controle dieren ligt dit bij NCC 4, 5 en 6 . Over het geheel genomen zijn de verschillen ten aanzien van NCC echter niet significant (T-toets).

We concluderen op grond van de bovenstaande analyse, dat de kans dat een bruinvis een lege maag had, niet gerelateerd was aan de groep (massa-sectie of controle) waartoe hij behoorde en dat de beide groepen op dit punt dus vergelijkbaar waren. Wel gaat het hebben van een lege maag samen met een hogere kans op vermagering en lijkt het stranden met een lege maag dus indicatief voor langdurigere problemen met de voedselopname. 


\subsubsection{DCC (Decompositie)}

De DCC geeft aan hoe "vers" een bruinvis is wanneer deze aanspoelt. De mate van rotting zou kunnen samen hangen met de afstand tot de kust waarop de bruinvis stierf: vers aangespoelde bruinvissen zullen over het algemeen dicht onder de kust zijn gestorven; rotte bruinvissen kunnen van verder uit de kust komen (maar dit hoeft niet zo te zijn). Als het dieet samenhangt met afstand tot de kust, zou DCC medebepalend kunnen zijn voor de maaginhoud.

Tabel 14 Percentages codes DCC van lege magen. Massa-sectie: 34 magen, controle: 73 magen. P volgens T-toets.

\begin{tabular}{|l|r|r|r|r|r|r|r|r|r|l|}
\hline \% DCC lege magen & 1 & 2 & 3 & 4 & 5 & Onbekend & N-DCC & Avg-DCC & stdev & P \\
\hline Massa-sectie & 0 & 14.7 & 20.6 & 50 & 11.8 & 2.9 & 34 & 3.3 & 0.98 & P $>0.1$ \\
\hline Controle & 2.7 & 8.2 & 13.7 & 68.5 & 6.9 & 0 & 73 & 3.3 & 0.97 & \\
\hline
\end{tabular}

In tabel 14 worden de percentages lege magen van de juveniele bruinvissen weergeven per DCC-code. De tabel laat zien dat bij DCC 3 en 4 (rot en erg rot) de meeste lege magen aanwezig zijn, zowel in de massa-sectie en controlegroep. Door middel van de T-toets is nagegaan of er onder de lege magen een verschil is ten aanzien van DCC tussen beide groepen, maar een dergelijk verschil werd niet gevonden. 


\subsection{Gevulde magen}

De overige magen van de geselecteerde groepen waren de "volle" magen, althans magen waarin minstens één prooirest werd aangetroffen.

\subsubsection{Massa maaginhoud van juveniele dieren uit de jaren 2011, 2012 en 2013}

Om te bepalen wat de invloed is van de seizoenen op de maaginhoud (in grammen gereconstrueerde prooimassa) zijn verspreidingsgrafieken met een trendlijn gemaakt voor de massa-sectie-dieren en voor de controlegroep (figuur 8 en 9). Hiervoor zijn alle "volle" magen, uit alle maanden meegenomen.

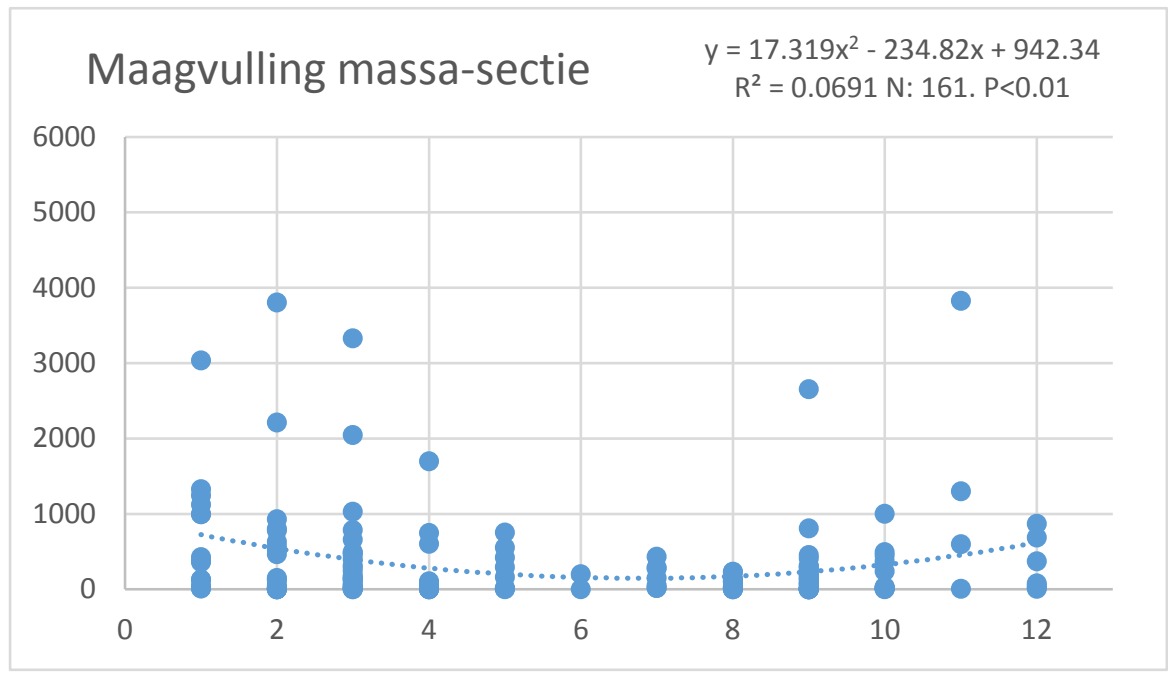

Figuur 8 Maagvulling (gram geconstrueerde prooimassa) bij de massa-sectie-bruinvissen, per maand.

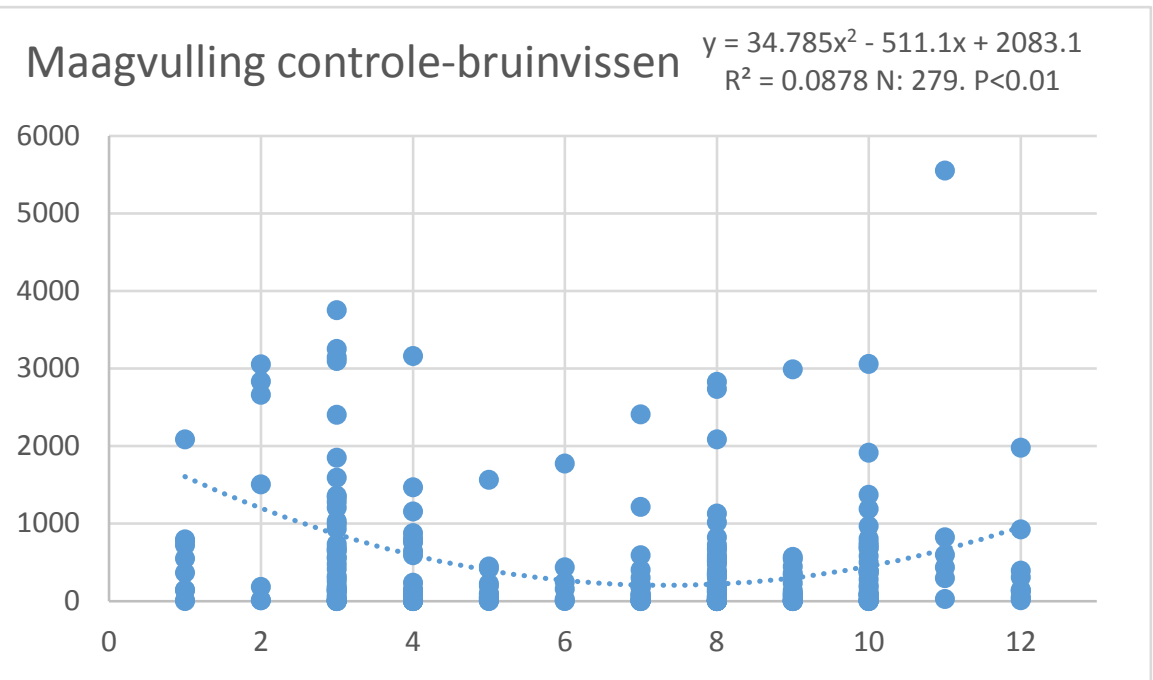

Figuur 9 Maagvulling (gram geconstrueerde prooimassa) bij de controle-bruinvissen, per maand. Eén januari-punt (15217.23 gram) is niet geplot (maar wel meegerekend).

De trend die in deze grafieken zichtbaar is geeft weer dat de hoeveelheid voedsel(resten) in een bruinvismaag een seizoenspatroon vertoont. 's Zomers eten bruinvissen minder dan in de wintermaanden (Leopold 2015a; Kastelein et al. 2018). Om recht te doen aan het verloop van de maaginhoud met de seizoenen is hier gekozen voor een kwadratische functie voor de regressievergelijkingen. Vanwege het seizoenseffect is het belangrijk dat tijdens de analyses hier rekening mee gehouden wordt. De selecties uit tabel 8 omvatten steeds maar een beperkt aantal opeenvolgende maanden, en zijn daarom geschikt voor de vergelijkende dieetanalyses. 


\subsection{Dieet}

In de tabellen hieronder is per bruinvisgroep voor verschillende prooigroepen beschreven in hoeveel magen deze werden gevonden en hoe groot de gereconstrueerde prooimassa (in grammen) was. Omdat de prooimassa's niet normaal verdeeld zijn (figuur $8 \& 9$ ), zijn deze voor de analyse getransformeerd door een viermachtswortel te gebruiken zoals beschreven is in paragraaf 3.4. Per bruinvisgroep is de gemiddelde massa, minimum- en maximum massa en de standaarddeviatie berekend. Zo is er per prooigroep een vergelijking gemaakt tussen de twee bruinvisgroepen. Of er een significant verschil aanwezig was, is te zien aan de kleur. Groen: niet significant, geel: wel significant (T-tests op vierde wortel-getransformeerde data, waarbij de lege magen zijn meegenomen).

Tabel 15 Prooigroepen vergeleken van alle massa-sectie ( $N$ : 191) en de controlegroep ( N: 399) bruinvissen. Prooimassa's als de vierde wortel-getransformeerde gemiddelde prooimassa weer (inclusief de nullen voor de legen magen).

\begin{tabular}{|c|c|c|c|c|c|c|c|}
\hline Clupeiden & Aantal, Totaal & $\mathrm{T}, \mathrm{df}$ & M-Avg & Min & Max & Stdev & Significatie \\
\hline Massa-sectie & $76 / 191$ & \multirow{2}{*}{$\begin{array}{l}3.011, \\
588\end{array}$} & 1.23 & 0 & 6.68 & 1.72 & \multirow[t]{2}{*}{$P<0.001$} \\
\hline Controle & $99 / 399$ & & 0.79 & 0 & 9.79 & 1.53 & \\
\hline \multicolumn{8}{|c|}{ Demersale vissen } \\
\hline Massa-sectie & $3 / 191$ & \multirow{2}{*}{$\begin{array}{l}2.842, \\
588\end{array}$} & 0.03 & 0 & 3.64 & 0.3 & \multirow[t]{2}{*}{$P<0.001$} \\
\hline Controle & $22 / 399$ & & 0.14 & 0 & 4.93 & 0.64 & \\
\hline \multicolumn{8}{|c|}{ Estuariene vissen } \\
\hline Massa-sectie & $31 / 191$ & \multirow{2}{*}{$\begin{array}{l}1.130, \\
588\end{array}$} & 0.45 & 0 & 7.72 & 1.17 & \multirow[t]{2}{*}{$\mathrm{P}>0.1$} \\
\hline Controle & $81 / 399$ & & 0.57 & 0 & 6.76 & 1.28 & \\
\hline \multicolumn{8}{|l|}{ Platvissen } \\
\hline Massa-sectie & $4 / 191$ & \multirow{2}{*}{$\begin{array}{l}1.301, \\
588\end{array}$} & 0.04 & 0 & 2.74 & 0.31 & \multirow[t]{2}{*}{$P>0.1$} \\
\hline Controle & $17 / 399$ & & 0.08 & 0 & 3.07 & 0.42 & \\
\hline \multicolumn{8}{|l|}{ Gadoiden } \\
\hline Massa-sectie & $44 / 191$ & \multirow{2}{*}{$\begin{array}{l}3.710, \\
588\end{array}$} & 0.81 & 0 & 13.15 & 1.79 & \multirow[t]{2}{*}{$P<0.001$} \\
\hline Controle & $156 / 399$ & & 1.43 & 0 & 9.67 & 2.11 & \\
\hline \multicolumn{8}{|l|}{ Grondels } \\
\hline Massa-sectie & $120 / 191$ & \multirow{2}{*}{$\begin{array}{l}0.607, \\
588\end{array}$} & 1.74 & 0 & 7.8 & 1.9 & \multirow[t]{2}{*}{$\mathrm{P}>0.1$} \\
\hline Controle & $250 / 399$ & & 1.64 & 0 & 7.48 & 1.81 & \\
\hline \multicolumn{8}{|l|}{ Invertebraten } \\
\hline Massa-sectie & $43 / 191$ & \multirow{2}{*}{$\begin{array}{l}0.206, \\
588\end{array}$} & 0.26 & 0 & 3.43 & 0.56 & \multirow[t]{2}{*}{$P>0.1$} \\
\hline Controle & $91 / 399$ & & 0.27 & 0 & 2.51 & 0.53 & \\
\hline \multicolumn{8}{|l|}{ Overige vissen } \\
\hline Massa-sectie & $4 / 191$ & \multirow{2}{*}{$\begin{array}{l}0.348, \\
588\end{array}$} & 0.05 & 0 & 2.98 & 0.35 & \multirow[t]{2}{*}{$P>0.1$} \\
\hline Controle & $12 / 399$ & & 0.04 & 0 & 2.94 & 0.27 & \\
\hline \multicolumn{8}{|c|}{ Pelagische vissen } \\
\hline Massa-sectie & $19 / 191$ & \multirow{2}{*}{$\begin{array}{l}1.188, \\
588 \\
\end{array}$} & 0.26 & 0 & 6.31 & 0.91 & \multirow[t]{2}{*}{$P>0.1$} \\
\hline Controle & $37 / 399$ & & 0.37 & 0 & 8.02 & 1.3 & \\
\hline \multicolumn{8}{|c|}{ Zandspieringen } \\
\hline Massa-sectie & $75 / 191$ & \multirow{2}{*}{$\begin{array}{l}2.157 \\
588 \\
\end{array}$} & 0.98 & 0 & 6.16 & 1.44 & \multirow[t]{2}{*}{$P<0.01$} \\
\hline Controle & $167 / 399$ & & 1.28 & 0 & 7.91 & 1.84 & \\
\hline Inktvissen & & & & & & & \\
\hline Massa-sectie & $44 / 191$ & 1.611 , & 0.43 & 0 & 4.2 & 0.85 & $P>0.1$ \\
\hline Controle & $70 / 399$ & 588 & 0.31 & 0 & 8.52 & 0.84 & \\
\hline
\end{tabular}

Over het algemeen komen de gegevens van de massa-sectie en de controlegroep met elkaar overeen en zijn er weinig significante verschillen te zien (zie tabel 15). De gevonden hoeveelheden clupeiden, demersale vissen, gadoiden en zandspieringen verschillen echter wel tussen de beide groepen. Tabel 15 geeft het dieet weer van de totale groep bruinvissen uit de jaren 2011, 2012 en 2013. In de dataexploratie is er besproken dat er vier selecties uit deze 3 jaren worden gemaakt om het dieet zonder invloed van co-variabelen te kunnen vergelijken. De vier tabellen hieronder (tabel 16, 17, 18 en 19) geven het dieet weer voor de geselecteerde maand/jaar combinaties. 
Tabel 16 Dieet per prooigroep vergelijking van de selectiegroep massa-sectie- ( $\mathrm{N}: 14)$ en controlegroep ( $\mathrm{N}: 38$ ) bruinvissen voor september \& oktober 2011. Prooimassa's als de vierde wortel-getransformeerde gemiddelde prooimassa weer (inclusief de nullen voor de lege magen).

\begin{tabular}{|c|c|c|c|c|c|c|c|}
\hline Clupeiden & Aantal, Totaal & $\mathrm{T}, \mathrm{df}$ & M-Avg & Min & Max & Stdev & Significatie \\
\hline Massa-sectie & $14 / 21$ & \multirow{2}{*}{$\begin{array}{l}0.134, \\
50\end{array}$} & 0.12 & 0 & 1.67 & 0.45 & \multirow[t]{2}{*}{$P>0.1$} \\
\hline Controle & $11 / 21$ & & 0.14 & 0 & 2.82 & 0.54 & \\
\hline \multicolumn{8}{|c|}{ Demersale vissen } \\
\hline Massa-sectie & $0 / 21$ & \multirow{2}{*}{$\begin{array}{l}1.203, \\
50 \\
\end{array}$} & 0 & 0 & 0 & 0 & \multirow[t]{2}{*}{$P>0.1$} \\
\hline Controle & $1 / 21$ & & 0.16 & 0 & 4.89 & 0.82 & \\
\hline \multicolumn{8}{|c|}{ Estuariene vissen } \\
\hline Massa-sectie & $4 / 21$ & \multirow{2}{*}{$\begin{array}{l}2.976, \\
50 \\
\end{array}$} & 0 & 0 & 0 & 0 & \multirow[t]{2}{*}{$P<0.001$} \\
\hline Controle & $11 / 21$ & & 0.7 & 0 & 5.44 & 1.45 & \\
\hline \multicolumn{8}{|l|}{ Platvissen } \\
\hline Massa-sectie & $0 / 21$ & \multirow{2}{*}{$\begin{array}{l}2.055, \\
50\end{array}$} & 0 & 0 & 0 & 0 & \multirow[t]{2}{*}{$P<0.01$} \\
\hline Controle & $0 / 21$ & & 0.18 & 0 & 1.94 & 0.54 & \\
\hline \multicolumn{8}{|l|}{ Gadoiden } \\
\hline Massa-sectie & $4 / 21$ & \multirow{2}{*}{$\begin{array}{l}1.551, \\
50\end{array}$} & 0.36 & 0 & 3.36 & 0.97 & \multirow[t]{2}{*}{$P>0.1$} \\
\hline Controle & $6 / 21$ & & 0.92 & 0 & 4.37 & 1.55 & \\
\hline \multicolumn{8}{|l|}{ Grondels } \\
\hline Massa-sectie & $12 / 21$ & \multirow{2}{*}{$\begin{array}{l}1.943, \\
50 \\
\end{array}$} & 1.27 & 0 & 4.01 & 1.46 & \multirow[t]{2}{*}{$P<0.05$} \\
\hline Controle & $20 / 21$ & & 2.26 & 0 & 7.37 & 2.02 & \\
\hline \multicolumn{8}{|l|}{ Invertebraten } \\
\hline Massa-sectie & $2 / 21$ & \multirow{2}{*}{$\begin{array}{l}1.650, \\
50 \\
\end{array}$} & 0.04 & 0 & 0.63 & 0.17 & \multirow[t]{2}{*}{$P>0.1$} \\
\hline Controle & $4 / 21$ & & 0.16 & 0 & 1.01 & 0.35 & \\
\hline \multicolumn{8}{|l|}{ Overige vissen } \\
\hline Massa-sectie & $0 / 21$ & & 0 & 0 & 0 & 0 & \multirow{2}{*}{$\begin{array}{l}\text { Niet te } \\
\text { bepalen }\end{array}$} \\
\hline Controle & $0 / 21$ & & 0 & 0 & 0 & 0 & \\
\hline \multicolumn{8}{|c|}{ Pelagische vissen } \\
\hline Massa-sectie & $1 / 21$ & & 0 & 0 & 0 & 0 & \multirow{2}{*}{\begin{tabular}{|l|}
$\begin{array}{l}\text { Niet te } \\
\text { bepalen }\end{array}$ \\
\end{tabular}} \\
\hline Controle & $4 / 21$ & & 0 & 0 & 0 & 0 & \\
\hline \multicolumn{8}{|c|}{ Zandspieringen } \\
\hline Massa-sectie & $9 / 21$ & \multirow{2}{*}{$\begin{array}{l}2.346, \\
50\end{array}$} & 0.26 & 0 & 1.86 & 0.65 & \multirow[t]{2}{*}{$P<0.01$} \\
\hline Controle & $9 / 21$ & & 0.98 & 0 & 5.38 & 1.56 & \\
\hline \multicolumn{8}{|l|}{ Inktvissen } \\
\hline Massa-sectie & $4 / 21$ & \multirow{2}{*}{$\begin{array}{l}3.260, \\
50 \\
\end{array}$} & 1.12 & 0 & 2.55 & 0.92 & $P<0.001$ \\
\hline Controle & $3 / 21$ & & 0.25 & 0 & 2.8 & 0.64 & \\
\hline
\end{tabular}

In tabel 16 is te zien dat de prooigroepen overige vissen en pelagische vissen in beide bruinvisgroepen niet voorkomen. De estuariene vissen, platvissen, grondels, zandspieringen en inktvissen laten een significant verschil zien tussen de twee bruinvisgroepen. Bij de estuariene vissen en platvissen zijn er geen prooien waargenomen bij de bruinvissen uit de massa-sectie. Er zijn meer magen waargenomen met grondels (massa-sectie: 57.14\%, controle: $81.57 \%$ ) en zandspieringen (massa-sectie: $14.29 \%$, controle: $36.84 \%$ ) in de controlegroep in vergelijking met de massa-sectie. Dit is ook te zien bij de inktvissen (massa-sectie: $64.29 \%$, controle: $15.79 \%$ ). Tabel 16 geeft ook weer dat in het najaar vooral gadoiden, grondels en zandspieringen worden gegeten. 
Tabel 17 Dieet per prooigroep vergelijking van de selectiegroep massa-sectie ( $N: 21)$ en controlegroep bruinvissen ( $\mathrm{N}: 21$ ) uit januari, februari \& maart, 2012.

\begin{tabular}{|c|c|c|c|c|c|c|c|}
\hline Clupeiden & Aantal, Totaal & $\mathrm{T}, \mathrm{df}$ & $M-A v g$ & Min & Max & Stdev & Significatie \\
\hline Massa-sectie & $14 / 21$ & \multirow{2}{*}{$\begin{array}{l}0.177, \\
40\end{array}$} & 2.22 & 0 & 5.49 & 1.93 & \multirow[t]{2}{*}{$P>0.1$} \\
\hline Controle & $11 / 21$ & & 2.34 & 0 & 9.79 & 2.43 & \\
\hline \multicolumn{8}{|c|}{ Demersale vissen } \\
\hline Massa-sectie & $0 / 21$ & \multirow{2}{*}{$\begin{array}{l}0.978, \\
40\end{array}$} & 0 & 0 & 0 & 0 & \multirow[t]{2}{*}{$P>0.1$} \\
\hline Controle & $1 / 21$ & & 0.16 & 0 & 3.45 & 0.75 & \\
\hline \multicolumn{8}{|c|}{ Estuariene vissen } \\
\hline Massa-sectie & $4 / 21$ & \multirow{2}{*}{$\begin{array}{l}2.206, \\
40\end{array}$} & 0.54 & 0 & 4.28 & 1.2 & \multirow[t]{2}{*}{$P<0.01$} \\
\hline Controle & $11 / 21$ & & 1.63 & 0 & 6.34 & 1.92 & \\
\hline \multicolumn{8}{|l|}{ Platvissen } \\
\hline Massa-sectie & $0 / 21$ & & 0 & 0 & 0 & 0 & \multirow{2}{*}{$\begin{array}{l}\text { Niet te } \\
\text { bepalen }\end{array}$} \\
\hline Controle & $0 / 21$ & & 0 & 0 & 0 & 0 & \\
\hline \multicolumn{8}{|l|}{ Gadoiden } \\
\hline Massa-sectie & $4 / 21$ & \multirow{2}{*}{$\begin{array}{l}0.906, \\
40\end{array}$} & 0.55 & 0 & 6.63 & 1.53 & \multirow[t]{2}{*}{$P>0.1$} \\
\hline Controle & $6 / 21$ & & 1.07 & 0 & 8.4 & 2.14 & \\
\hline \multicolumn{8}{|l|}{ Grondels } \\
\hline Massa-sectie & $12 / 21$ & \multirow{2}{*}{$\begin{array}{l}2.134, \\
40\end{array}$} & 1.68 & 0 & 6.84 & 2.14 & \multirow[t]{2}{*}{$P<0.01$} \\
\hline Controle & $20 / 21$ & & 3.06 & 0 & 7.44 & 2.05 & \\
\hline \multicolumn{8}{|l|}{ Invertebraten } \\
\hline Massa-sectie & $2 / 21$ & \multirow{2}{*}{$\begin{array}{l}1.179, \\
40\end{array}$} & 0.09 & 0 & 0.98 & 0.29 & \multirow[t]{2}{*}{$P>0.1$} \\
\hline Controle & $4 / 21$ & & 0.25 & 0 & 1.78 & 0.55 & \\
\hline \multicolumn{8}{|l|}{ Overige vissen } \\
\hline Massa-sectie & $0 / 21$ & & 0 & 0 & 0 & 0 & \multirow{2}{*}{$\begin{array}{l}\text { Niet te } \\
\text { bepalen }\end{array}$} \\
\hline Controle & $0 / 21$ & & 0 & 0 & 0 & 0 & \\
\hline \multicolumn{8}{|c|}{ Pelagische vissen } \\
\hline Massa-sectie & $1 / 21$ & \multirow{2}{*}{$\begin{array}{l}1.487, \\
40\end{array}$} & 0.09 & 0 & 1.91 & 0.42 & \multirow[t]{2}{*}{$P>0.1$} \\
\hline Controle & $4 / 21$ & & 0.43 & 0 & 3.11 & 0.96 & \\
\hline \multicolumn{8}{|c|}{ Zandspieringen } \\
\hline Massa-sectie & $9 / 21$ & \multirow{2}{*}{$\begin{array}{l}0.911, \\
40\end{array}$} & 0.88 & 0 & 2.83 & 1.09 & \multirow[t]{2}{*}{$P>0.1$} \\
\hline Controle & $9 / 21$ & & 1.29 & 0 & 4.93 & 1.75 & \\
\hline \multicolumn{8}{|l|}{ Inktvissen } \\
\hline Massa-sectie & $4 / 21$ & \multirow{2}{*}{$\begin{array}{l}0.080, \\
40\end{array}$} & 0.33 & 0 & 3.04 & 0.78 & $P>0.1$ \\
\hline Controle & $3 / 21$ & & 0.31 & 0 & 3.3 & 0.84 & \\
\hline
\end{tabular}

Tabel 17 laat zien dat over het algemeen de twee bruinvisgroepen qua dieet gelijk zijn aan elkaar. Alleen bij de estuariene vissen en grondels zijn er significante verschillen waargenomen. De relatief grote standaarddeviaties en maxima voor de prooimassa's suggereren dat er enkele uitschieters in prooimassa zijn, die het gemiddelde omhoog halen. In deze tabel is ook zichtbaar dat de clupeiden, estuariene vissen en grondels relatief veel gegeten worden in de winter. 
Tabel 18 Dieet per prooigroep vergelijking van de selectiegroep massa-sectie ( $: 42)$ en controlegroep ( $\mathrm{N}: 43$ ) bruinvissen uit juli, augustus, september \& oktober, 2012. Prooimassa's als de vierde wortel-getransformeerde gemiddelde prooimassa weer (inclusief de nullen voor de legen magen).

\begin{tabular}{|c|c|c|c|c|c|c|c|}
\hline Clupeiden & Aantal, Totaal & $\mathrm{T}, \mathrm{df}$ & M-Avg & Min & Max & Stdev & Significatie \\
\hline Massa-sectie & $6 / 42$ & \multirow{2}{*}{$\begin{array}{l}0.835, \\
83\end{array}$} & 0.41 & 0 & 4.44 & 1.07 & \multirow[t]{2}{*}{$P>0.1$} \\
\hline Controle & $3 / 43$ & & 0.23 & 0 & 4.41 & 0.91 & \\
\hline \multicolumn{8}{|c|}{ Demersale vissen } \\
\hline Massa-sectie & $3 / 42$ & \multirow{2}{*}{$\begin{array}{l}0.158, \\
83\end{array}$} & 0.15 & 0 & 3.64 & 0.62 & \multirow[t]{2}{*}{$P>0.1$} \\
\hline Controle & $4 / 43$ & & 0.17 & 0 & 2.08 & 0.54 & \\
\hline \multicolumn{8}{|c|}{ Estuariene vissen } \\
\hline Massa-sectie & $2 / 42$ & \multirow{2}{*}{$\begin{array}{l}0.887, \\
83\end{array}$} & 0.17 & 0 & 4.12 & 0.78 & \multirow[t]{2}{*}{$P>0.1$} \\
\hline Controle & $5 / 43$ & & 0.37 & 0 & 6.76 & 1.25 & \\
\hline \multicolumn{8}{|l|}{ Platvissen } \\
\hline Massa-sectie & $4 / 42$ & \multirow{2}{*}{$\begin{array}{l}1.994, \\
83\end{array}$} & 0.2 & 0 & 2.74 & 0.65 & \multirow[t]{2}{*}{$P<0.01$} \\
\hline Controle & $0 / 43$ & & 0 & 0 & 0 & 0 & \\
\hline \multicolumn{8}{|l|}{ Gadoiden } \\
\hline Massa-sectie & $13 / 42$ & \multirow{2}{*}{$\begin{array}{l}1.137 \\
83\end{array}$} & 0.82 & 0 & 4.6 & 1.39 & \multirow[t]{2}{*}{$P>0.1$} \\
\hline Controle & $15 / 43$ & & 1.23 & 0 & 7 & 1.9 & \\
\hline \multicolumn{8}{|l|}{ Grondels } \\
\hline Massa-sectie & $27 / 42$ & \multirow{2}{*}{$\begin{array}{l}0.740, \\
83\end{array}$} & 1.59 & 0 & 7.14 & 1.74 & \multirow[t]{2}{*}{$P>0.1$} \\
\hline Controle & $26 / 43$ & & 1.32 & 0 & 6.5 & 1.62 & \\
\hline \multicolumn{8}{|l|}{ Invertebraten } \\
\hline Massa-sectie & $8 / 42$ & \multirow{2}{*}{$\begin{array}{l}0.801, \\
83\end{array}$} & 0.27 & 0 & 3.09 & 0.63 & \multirow[t]{2}{*}{$P>0.1$} \\
\hline Controle & $8 / 43$ & & 0.18 & 0 & 1.15 & 0.37 & \\
\hline \multicolumn{8}{|l|}{ Overige vissen } \\
\hline Massa-sectie & $4 / 42$ & \multirow{2}{*}{$\begin{array}{l}1.210, \\
83\end{array}$} & 0.22 & 0 & 2.98 & 0.72 & \multirow[t]{2}{*}{$P>0.1$} \\
\hline Controle & $2 / 43$ & & 0.07 & 0 & 2.3 & 0.36 & \\
\hline \multicolumn{8}{|c|}{ Pelagische vissen } \\
\hline Massa-sectie & $1 / 42$ & \multirow{2}{*}{$\begin{array}{l}0.361, \\
83\end{array}$} & 0.05 & 0 & 1.92 & 0.3 & \multirow[t]{2}{*}{$P>0.1$} \\
\hline Controle & $1 / 43$ & & 0.03 & 0 & 1.33 & 0.2 & \\
\hline \multicolumn{8}{|c|}{ Zandspieringen } \\
\hline Massa-sectie & $15 / 42$ & \multirow{2}{*}{$\begin{array}{l}0.351, \\
83\end{array}$} & 0.91 & 0 & 4.56 & 1.44 & \multirow[t]{2}{*}{$P>0.1$} \\
\hline Controle & $12 / 43$ & & 0.8 & 0 & 4.83 & 1.45 & \\
\hline Inktvissen & & & & & & & \\
\hline Massa-sectie & $13 / 42$ & 1.650 , & 0.66 & 0 & 3.45 & 1.08 & $P>0.1$ \\
\hline Controle & $10 / 43$ & & 0.34 & 0 & 2.17 & 0.65 & \\
\hline
\end{tabular}

In vergelijking tot de winter (tabel 17) werden in de zomermaanden (juli, augustus, september en oktober) meer gadoiden, grondels, zandspieringen en inktvissen gegeten door de bruinvissen (tabel 18). In de zomermaanden hebben bruinvissen dus een relatief bredere prooikeuze. Ook hier is het dieet tussen de twee bruinvisgroepen weinig verschillend van elkaar. Alleen voor de platvissen wordt een significant verschil gevonden: in de massa-sectie-bruinvissen zijn er resten van platvissen waargenomen en bij de controlegroep niet. 
Tabel 19 Dieet per prooigroep vergelijking van de selectiegroep massa-sectie ( $N: 42)$ en controlegroep ( $\mathrm{N}: 30)$ bruinvissen uit maart, april \& mei, 2013. Prooimassa's als de vierde wortelgetransformeerde gemiddelde prooimassa weer (inclusief de nullen voor de legen magen).

\begin{tabular}{|c|c|c|c|c|c|c|c|}
\hline Clupeiden & Aantal, Totaal & $\mathrm{T}, \mathrm{df}$ & M-Avg & Min & Max & Stdev & Significatie \\
\hline Massa-sectie & $21 / 42$ & \multirow{2}{*}{$\begin{array}{l}0.629, \\
70\end{array}$} & 1.45 & 0 & 6.68 & 1.73 & \multirow[t]{2}{*}{$P>0.1$} \\
\hline Controle & $17 / 30$ & & 1.71 & 0 & 5.44 & 1.73 & \\
\hline \multicolumn{8}{|c|}{ Demersale vissen } \\
\hline Massa-sectie & $0 / 42$ & \multirow{2}{*}{$\begin{array}{l}1.095 \\
70 \\
\end{array}$} & 0 & 0 & 0 & 0 & \multirow[t]{2}{*}{$P>0.1$} \\
\hline Controle & $1 / 30$ & & 0.06 & 0 & 1.66 & 0.3 & \\
\hline \multicolumn{8}{|c|}{ Estuariene vissen } \\
\hline Massa-sectie & $14 / 42$ & \multirow{2}{*}{$\begin{array}{l}0.679, \\
70 \\
\end{array}$} & 0.82 & 0 & 4.84 & 1.37 & \multirow[t]{2}{*}{$P>0.1$} \\
\hline Controle & $12 / 30$ & & 1.05 & 0 & 4.62 & 1.45 & \\
\hline \multicolumn{8}{|l|}{ Platvissen } \\
\hline Massa-sectie & $0 / 42$ & \multirow{2}{*}{$\begin{array}{l}1.598, \\
70 \\
\end{array}$} & 0 & 0 & 0 & 0 & \multirow[t]{2}{*}{$P>0.1$} \\
\hline Controle & $3 / 30$ & & 0.14 & 0 & 2.1 & 0.48 & \\
\hline \multicolumn{8}{|l|}{ Gadoiden } \\
\hline Massa-sectie & $2 / 42$ & \multirow{2}{*}{$\begin{array}{l}2.168, \\
70 \\
\end{array}$} & 0.1 & 0 & 3.82 & 0.59 & \multirow[t]{2}{*}{$P<0.01$} \\
\hline Controle & $8 / 30$ & & 0.64 & 0 & 4.29 & 1.27 & \\
\hline \multicolumn{8}{|l|}{ Grondels } \\
\hline Massa-sectie & $33 / 42$ & \multirow{2}{*}{$\begin{array}{l}1.508, \\
70 \\
\end{array}$} & 1.9 & 0 & 5.62 & 1.57 & \multirow[t]{2}{*}{$P>0.1$} \\
\hline Controle & $25 / 30$ & & 2.57 & 0 & 7.48 & 2.04 & \\
\hline \multicolumn{8}{|l|}{ Invertebraten } \\
\hline Massa-sectie & $11 / 42$ & \multirow{2}{*}{$\begin{array}{l}1.848, \\
70 \\
\end{array}$} & 0.25 & 0 & 1.78 & 0.49 & \multirow[t]{2}{*}{$P<0.05$} \\
\hline Controle & $13 / 30$ & & 0.51 & 0 & 1.92 & 0.65 & \\
\hline \multicolumn{8}{|l|}{ Overige vissen } \\
\hline Massa-sectie & $0 / 42$ & & 0 & 0 & 0 & 0 & \multirow{2}{*}{$\begin{array}{l}\text { Niet te } \\
\text { bepalen }\end{array}$} \\
\hline Controle & $0 / 30$ & & 0 & 0 & 0 & 0 & \\
\hline \multicolumn{8}{|c|}{ Pelagische vissen } \\
\hline Massa-sectie & $9 / 42$ & \multirow{2}{*}{$\begin{array}{l}0.388, \\
70 \\
\end{array}$} & 0.45 & 0 & 4.14 & 1 & \multirow[t]{2}{*}{$P>0.1$} \\
\hline Controle & $4 / 30$ & & 0.36 & 0 & 3.2 & 0.95 & \\
\hline \multicolumn{8}{|c|}{ Zandspieringen } \\
\hline Massa-sectie & $18 / 42$ & \multirow{2}{*}{$\begin{array}{l}1.150, \\
70\end{array}$} & 0.9 & 0 & 5.1 & 1.21 & \multirow[t]{2}{*}{$P>0.1$} \\
\hline Controle & $14 / 30$ & & 1.34 & 0 & 5.96 & 1.83 & \\
\hline \multicolumn{8}{|l|}{ Inktvissen } \\
\hline Massa-sectie & $5 / 42$ & 1.398, & 0.18 & 0 & 1.64 & 0.5 & $P>0.1$ \\
\hline Controle & $8 / 30$ & 70 & 0.38 & 0 & 2.07 & 0.66 & \\
\hline
\end{tabular}

Over het algemeen worden er in deze periode weinig significante verschillen gevonden (tabel 19). De prooigroep overige vissen is niet getest op significantie in het dieet omdat er geen prooien zijn waargenomen in beide bruinvisgroepen. Bij de prooigroepen gadoiden en invertebraten werden kleine verschillen gevonden. In verhouding zijn er meer controle-bruinvissen waargenomen met gadoiden dan massa-sectie-dieren (massa-sectie: 4,76\%, controle: $26,67 \%$ ). Bij de invertebraten was dit ook het geval (massa-sectie: $26,19 \%$, controle: $43,33 \%$ ) en mogelijk hangt een en ander met elkaar samen, als veel van de invertebraten eigenlijk de prooien waren van de gadoiden. De selectiegroep uit 2013 omvat het voorjaar (maart, april \& mei) waarin voornamelijk clupeiden, estuariene vissen, grondels en zandspieringen werden gegeten. Vooral de clupeiden en estuariene vissen werden vaker waargenomen in de winter- en voorjaar bruinvissen (tabel 17). 


\subsection{PERMANOVA analyse}

Om het dieet van de massa-sectie-bruinvissen en de controle-bruinvissen als geheel te kunnen vergelijken zijn er vier afzonderlijke PERMANOVA analyses uitgevoerd op de geselecteerde groepen (paragraaf 3.2.8). De resultaten van deze analyses worden hieronder besproken.

Tabel 20 PERMANOVA resultaten van de selecties uit de jaren 2011, 2012 en 2013 (op basis van vierde machts-wortel getransformeerde prooimassa's per prooigroep, per bruinvis)

\begin{tabular}{|c|c|c|c|c|}
\hline Selectie & $\mathrm{df}$ & Pseudo-F & $\mathrm{P}($ perm $)$ & Unique perms \\
\hline Najaar 2011 & 1 & 5.0425 & 0.001 & 998 \\
\hline Winter 2012 & 1 & 1.7859 & 0.14 & 999 \\
\hline Zomer 2012 & 1 & 0.55462 & 0.777 & 998 \\
\hline Voorjaar 2013 & 1 & 0.56212 & 0.748 & 997 \\
\hline
\end{tabular}

Tabel 20 geeft alleen een significant verschil aan voor najaar 2011 . Kijkend naar tabel 16 is te verwachten dat deze significantie vooral gebaseerd is op de prooigroepen grondels en zandspieringen. De uitkomst van de SIMPER analyse (Tabel 21) bevestigt dat deze groepen het meeste bijdragen aan de uitkomst van de PERMANOVA analyse. De overige selecties (uit de jaren 2012 en 2013) geven geen significant verschil weer. Het dieet van de twee bruinvisgroepen verschilt voor deze selecties van bruinvissen niet van elkaar. De significante verschillen in tabellen 17, 18 en 19 voor enkele afzonderlijke prooigroepen waren achteraf niet overheersend genoeg om de gehele selectie als verschillend te zien.

Tabel 21 SI MPER resultaten van de selecties uit de jaren 2011, 2012 en 2013 (op basis van vierde machts-wortel getransformeerde prooimassa's per prooigroep, per bruinvis)

\begin{tabular}{|l|r|r|r|r|r|r|}
\hline Prooigroepen & \multicolumn{1}{|l|}{ Av.Abund } & Av.Abund & \multicolumn{1}{l|}{ Av.Diss } & \multicolumn{1}{l|}{ Diss/SD } & \multicolumn{1}{l|}{ Contrib\% } & \multicolumn{1}{l|}{ Cum.\% } \\
\hline Grondels & 2.26 & 1.27 & 25.25 & 1.31 & 32.8 & 32.8 \\
\hline Inktvissen & 0.25 & 1.12 & 14.41 & 1 & 18.71 & 51.51 \\
\hline Zandspieringen & 0.98 & 0.26 & 11.82 & 0.68 & 15.35 & 66.87 \\
\hline Gadoiden & 0.92 & 0.36 & 10.41 & 0.69 & 13.52 & 80.39 \\
\hline Est.vissen & 0.7 & 0 & 6.36 & 0.43 & 8.26 & 88.64 \\
\hline Clupeiden & 0.14 & 0.12 & 2.83 & 0.36 & 3.68 & 92.33 \\
\hline
\end{tabular}




\section{Discussie}

Door de extra financiering van het Ministerie van LNV in 2014 is de voorraad bruinvissen met een massasectie 'weggesneden' voor het dieet-onderzoek, en is zo veel mogelijk informatie uit dit opgeslagen materiaal gehaald. Deze informatie is ingebracht in het lopende onderzoek naar het dieet van de bruinvis in Nederland, waardoor een vergelijking gemaakt kan worden tussen het dieet van de "massa-sectie bruinvissen" en bruinvissen die binnen het reguliere onderzoek aan bruinvissen vallen. Het doel van dit rapport was om na te gaan in hoeverre de verzamelde magen van de massa-sectie een dieet te zien geven, dat vergelijkbaar is met het dieet op basis van de reguliere secties. In dat geval namelijk, kunnen dieren uit massa-secties, of ook minder verse bruinvissen bij het reguliere onderzoek worden betrokken. Hierdoor zouden de gereduceerde aantallen magen, die beschikbaar komen na pathologisch onderzoek, aangevuld kunnen worden met magen van bruinvissen die nu ongeschikt worden geacht voor een (volledig) pathologisch onderzoek, waardoor het dieet-onderzoek aanzienlijk aan kracht zou kunnen winnen, tegen relatief geringe meerkosten.

\subsection{Inventarisatie- en verwerkingsprocedures}

Deze studie vergelijkt de maaginhouden van bruinvissen, afkomstig van verschillende secties. Dieren in de controlegroep hebben een volledige sectie (Begeman et al. 2013) ondergaan en de massa-sectiedieren zijn met een versimpeld protocol verwerkt. Uit de massa-secties kwamen 247 magen beschikbaar voor vergelijkend dieet-onderzoek. Omdat er voor het onderhavige vergelijkbare dieetonderzoek 'zuivere' vergelijkingen gemaakt moesten worden tussen massa-sectie-bruinvissen en controle-bruinvissen is er een selectie van magen gemaakt. Binnen de twee te onderzoeken groepen is gezocht naar voldoende grote subsets van magen van juveniele dieren (de meest voorkomende leeftijdscategorie onder de gestrande bruinvissen), afkomstig uit een beperkte tijdspanne van aanspoelen. Door deze selecties werd de invloed van seizoen en jaar van aanspoelen, en van de leeftijd van de bruinvissen, uitgesloten.

Tijdens de secties, voorafgaand aan het dieet-onderzoek zijn verschillende parameters van de dieren beschreven zoals leeftijd, geslacht, vindplaats, datum van de stranding, DCC en NCC. Deze gegevens zijn niet altijd genoteerd en sommige magen konden dan ook niet worden meegenomen in bepaalde vergelijkingen. Omdat echter de parameters geslacht, DCC en vindplaats van ondergeschikt belang zijn bij de prooikeuze van een bruinvis (Leopold 2015a), bleven deze omissies zonder verdere gevolgen.

In het dieetonderzoek van Leopold (2015a) zijn de individuele prooisoorten samengevoegd in een beperkt aantal prooigroepen. Deze prooigroepen hebben een taxonomische en een ecologische basis: prooisoorten die taxonomisch dicht bij elkaar staan en die bovendien sterke overeenkomsten vertonen in lichaamsvorm, levenswijze en habitat zijn samen genomen voor de analyses. Deze groepering van prooien is ook gebruikt voor dit onderzoek (tabel 8), om het aantal afzonderlijke "prooien" en daarmee het aantal zeldzame prooien beperkt te houden. Leopold (2015a) maakt aannemelijk dat het voor een bruinvis weinig uitmaakt welke prooisoort hij binnen een bepaalde prooigroep eet, wanneer de kosten van het foerageren en de baten (de energieopbrengst) tussen de verschillende soorten binnen een prooigroep onderling weinig van elkaar verschillen. Zo zullen bijvoorbeeld de kosten en de baten van verschillende soorten grondels voor een bruinvis als prooi niet veel uitmaken (door hun uiterlijke gelijkenissen en voedingswaarde) zodat deze in een prooigroep geplaatst kunnen worden. Zo wordt verwacht dat de verschillende prooisoorten, zeker voor de vier belangrijkste prooigroepen; kabeljauwachtigen, grondels, zandspieringen en haringachtigen (Leopold 2015a) binnen deze prooigroepen gelijkwaardig aan elkaar zijn voor de bruinvis. Eventuele determinatiefouten binnen de prooigroepen maken dan bovendien geen verschil voor de analyses. 
De bruinvissen in zowel de controlegroep als de massa-sectie-groep zijn door de jaren heen door verschillende mensen onderzocht. Deze onderzoekers/studenten hebben allemaal in hetzelfde databestand gewerkt. De wijze van determineren, meten en invoeren is altijd gecontroleerd door dezelfde persoon (Mardik Leopold). Fouten die toch in het databestand zijn ontstaan zijn door een aantal controleslagen nog zoveel mogelijk verwijderd, voorafgaand aan de hier gepresenteerde analyses.

\subsection{Resultaten}

In dit onderzoek is ook gekeken naar de lege magen in beide groepen bruinvissen. De verhouding lege magen tegenover gevulde magen in beide bruinvisgroepen was vrijwel gelijk aan elkaar. Ook op dit punt verschillen de magen, afkomstig van dieren uit de massa-secties dus niet van die in de controlegroep. Tabel 12 laat zien dat er in de zomermaanden meer bruinvissen waren met lege magen. Bruinvissen hebben blijkbaar meer moeite met het foerageren, of minder de behoefte om constant te eten, in de zomermaanden dan in de rest van het jaar. Figuren 8 en 9 uit paragraaf 4.3.1 laten dit ook zien.

Een bruinvis moet dagelijks ongeveer $10 \%$ van zijn lichaamsgewicht aan prooien eten om aan voldoende voedingsstoffen te komen (Leopold 2015a). Jonge dieren eten voornamelijk grondels omdat deze gemakkelijk te vangen en abundant zijn. Grondels zijn echter zowel klein als arm aan calorieën en een jonge bruinvis zal veel grondels moeten eten om genoeg voedingsstoffen binnen te krijgen. Wanneer de bruinvis ouder wordt zal hij over moeten gaan op grotere en/of vettere (en dus calorierijkere) prooien (Leopold 2015a). Dit komt echter in deze studie niet nader aan de orde, omdat hier alleen juveniele bruinvissen zijn bestudeerd. Zoals te zien is in de tabellen uit paragraaf 4.4 worden verschillende prooigroepen in verschillende seizoenen het meest gegeten. De selecties die gemaakt zijn voor de analyses vallen binnen alle maanden van het jaar en geven dus ook een beeld van de favoriete prooien in bepaalde periodes.

De PERMANOVA analyse in paragraaf 4.5 laat zien dat er alleen in september/oktober 2011 een significant verschil was tussen het dieet van de massa-sectie-dieren en de controle-bruinvissen. Dit verschil is terug te voeren op verscheidene prooigroepen (tabel 16 in paragraaf 4.4). De estuariene vissen en de platvissen zijn niet waargenomen in de massa-sectie-bruinvissen, maar wel bij enkele dieren in de controlegroep. Deze groep was echter aanzienlijk groter dan de groep massa-sectie-dieren in deze periode (tabel 8), waardoor de kans op een vondst van een relatief zeldzame prooi groter was in de controlegroep. De SIMPER analyse kent relatief weinig waarde toe aan (het ontbreken van) deze zeldzame prooien in de massa-sectie-groep en laat zien dat de grondels en zandspieringen het meeste bijdragen aan het verschil in dieet (tabel 21). Zoals te zien is in de tabel 16 zijn er meer van beide prooigroepen in de controle-groep-dieren waargenomen dan in de dieren uit de massa-sectie. Met slechts 14 dieren in de groep van de massa-sectie was het beschikbare aantal magen voor een vergelijking met de controlegroep wellicht te klein voor een deugdelijke vergelijking van het dieet. De aantallen dieren in de andere groepen die werden vergeleken zijn steeds groter en bovendien relatief gelijk aan elkaar (tabel 8), waardoor er meer gewicht toegekend wordt aan de uitkomsten van die vergelijkingen. Aangezien slechts een van de vier analyses een significant verschil weergeeft tussen het dieet van de massa-sectie en de controle-bruinvissen, terwijl dit bovendien de vergelijking betreft die stoelt op het kleinste aantal dieren, is onze conclusie, dat verschillen in dieet tussen de controle en massa-sectie-groep minimaal zijn. Magen, afkomstig uit massa-secties bij bruinvissen zijn dus geschikt voor dieet-onderzoek. 


\section{Conclusie}

De nulhypothese voor deze dieetstudie, dat "als gecorrigeerd wordt voor de belangrijkste factoren, er geen verschil te zien is in het dieet van de massa-sectie-bruinvissen en de controlegroep-bruinvissen" kon op hoofdlijnen worden bevestigd. Binnen de grote groep van 283 bruinvissen die in een massa-sectie werden onderzocht waren er vier groepen dieren die voldoende uniform waren in termen van leeftijd (juveniel) en tijdstip van stranden, en bovendien in voldoende aantallen aanwezig waren, dat er een zinvolle vergelijking kon worden gemaakt tussen de voedselresten in hun magen (het "dieet") en die in magen van gelijksoortige bruinvissen uit het reguliere, doorlopende dieetonderzoek aan bruinvissen (de controlegroep). Voor drie van deze groepen: gestrand in januari-maart 2012 (21 massa-sectie-dieren versus 21 controledieren); gestrand in juli-oktober 2012 (42 vs. 43); en gestrand in maart-mei 2013 (42 vs. 30) werd geen significant verschil in dieet gevonden. Voor een relatief kleine vierde groep, dieren die zijn gestrand in september-oktober 2011 (14 vs. 38 dieren) werd wel een verschil gevonden. In deze periode hadden de massa-sectie-dieren gemiddeld minder kabeljauwachtigen, grondels, zandspieringen en inktvissen gegeten dan de controledieren en ontbrak een aantal wat zeldzamere prooien in het dieet van de massa-sectie-dieren, terwijl ze wel voorkwamen in de controlegroep. Mogelijk hingen deze observaties samen met het feit dat het aantal beschikbare dieren uit de massa-sectie (14) voor deze groep relatief klein was.

Dit laatste punt, dat de kans op het vinden van "verschillen" wellicht relatief groot is als maar weinig dieren beschikbaar zijn voor vergelijkend onderzoek, vormt een punt van zorg. Met het huidige jaarlijkse sectie-quotum van 50 bruinvissen staat de kracht van de monitoring onder druk en het verdient een aanbeveling te overwegen om dit jaarlijkse quotum uit te breiden. Dit kan op een relatief goedkopere manier wanneer naast 50 verse bruinvissen, ook een aantal minder verse (DCC 3) dieren voor onderzoek wordt verzameld. Dieren in deze categorie zouden dan een minder uitgebreide sectie kunnen ondergaan, waarbij echter nog steeds ook een aantal opvallende doodsoorzaken (bijvangst, predatie) kan worden vastgesteld. Het vaststellen van bijvangst van bruinvissen is hierbij van bijzonder belang, omdat dieren ook verder uit de kust in netten zwemmen en verdrinken. Dieren die verder uit de kust sterven, hebben een langere tijd nodig om te stranden en zijn daardoor gemiddeld minder vers dan dieren die vlak onder de kust sterven. Het niet meer onderzoeken van DCC 3 dieren heeft daardoor het risico in zich dat het percentage dieren waarbij bijvangst als doodsoorzaak wordt vastgesteld, daalt (Begeman et al. 2013). Dit is echter een daling die slechts te wijten is aan een procedure-verandering, waarmee de zeggingskracht van de monitoring daalt.

Ook voor het monitoren van dieet zijn meer magen dan 50 per jaar gewenst. Voor het uitvoeren van dieet-onderzoek moet rekening worden gehouden met diverse co-variabelen (onder meer: jaar, seizoen, leeftijd en voedingstoestand van de bruinvis). Onder de onderzochte dieren vallen er ook altijd enkele af omdat deze een lege maag hebben. Zoals te zien is in paragraaf 3.2.8 blijven er, ook wanneer er honderden dieren zijn onderzocht, toch vrij weinig bruinvissen over wanneer er een vergelijking moet worden gemaakt tussen twee groepen. Hetzelfde zal gelden wanneer bijvoorbeeld veranderingen in het dieet door de tijd, bijvoorbeeld door veranderingen in visbestanden, moeten worden gevolgd

Alles overziende wordt geconcludeerd dat de magen, afkomstig uit de massa-sectie een beeld van het dieet van de bruinvis opleveren dat goed overeen komt het beeld verkregen middels de reguliere secties. Magen van dieren uit de massa-sectie zijn dus geschikt voor dieet-onderzoek en het huidige krappe aantal dieren dat regulier wordt onderzocht, zou voor het dieetwerk probleemloos kunnen worden aangevuld met dieren die voor een eenvoudigere, massa-sectie verzameld worden. 


\section{Literatuur}

Aarefjord H., Bjørge A. \& Kinze C.C. 1995. Diet of the harbour porpoise Phocoena phocoena in Scandinavian waters. Report of the international Whaling Commision. Special Issue 16: 211-215.

Anderson M.J . 2001. A new method for non-parametric multivariate analysis of variance. Austr. Ecol. 26: 32-46.

Arnold P.W. 1972. Predation on harbour porpoise, Phocoena phocoena, by white shark, Carcharodon carcharias. J. Fish. Res. Board Can. 29: 1213-1214.

Begeman L., IJ sseldijk L.L. \& Gröne A. 2013. Postmortaal onderzoek van bruinvissen (Phocoena phocoena) uit Nederlandse wateren van 2009 tot 2013. Departement Pathobiologie, Faculteit Diergeneeskunde, Universiteit Utrecht, 50p.

Bjørge A., M. Skern-Mauritzen and M.C. Rossman. 2013. Estimated bycatch of harbour porpoise (Phocoena phocoena) in two coastal gillnet fisheries in Norway, 2006-2008. Mitigation and implications for conservation. Biological Conservation 234, 161: 164-173.

Bjørge A. \& Tolley K.A. 2008. Harbor porpoise Phocoena phocoena Encyclopedia of Marine Mammals (edited by William F. Perrin, Bernd Wursig, and J. G.M. Thewissen). Academic Press; 2nd edition: 530-532.

Van Bleijswijk J.D.L., Begeman L., Witte H.J., IJ sseldijk L.L., Brasseur S.M.J.M., Gröne A \& Leopold M.F. 2014. Detection of grey seal DNA Halichoerus grypus in attack wounds in stranded harbour porpoises Phocoena phocoena. Mar. Ecol. Prog. Ser. 513: 277-281.

Börjesson P., Berggren P. \& Ganning B. 2003. Diet of harbor porpoises in the Kattengat and Skagerrak seas: accouting for individual variation and sample size. Mar. Mamm. Sci. 19, 1: 38-58.

Bouveroux T., Kiska J.J., Heithaus M.R., Jauniaux T. \& Pezeril S. 2014. Direct evidance for grey seal (Halichoerus grypus) predation and scavenging on harbour porpoises (Phocoena phocoena). Mar. Mamm. Sci. 30: $1542-1548$.

Clarke K.R., \& Gorley R.N. 2015. PRIMER v7: User Manual/Tutorial. PRIMER-E, Plymouth, 296 pages.

Dahlheim M.E. \& White P.A. 2010. Ecological aspects of transient killer whales Orcinus orca as predators in southeastern Alaska. Wildl. Biol. 16: 308-322.

Van Dam S., Solé L., IJ sseldijk L.L., Begeman L.\& Leopold M.F. 2017. The semi-enclosed tidal bay Eastern Scheldt in the Netherlands: porpoise heaven or porpoise prison? Lutra 60: 5-18.

De Maddalena A. \& Heim W. 2012. Mediterranean great white sharks: a comprehensive study including all recorded sightings. McFarland \& Company, Inc., Publishers, Jefferson, North Carolina.

Fontaine M.C., Tolley K.A., Michaux J.R., Birkun J r A., Ferreira, M., Jauniaux T., Llavona A., Özturk B., Özturk A.A., Ridoux V., Rogan E., Sequeira M., Bouquegneau J \& Baird., A.J.E. 2010. Genetic and historic evidence for climate-driven population fragmentation in a top cetacean predator: the harbour porpoises in European water. Proceedings of The Royal Society B, 227, 1695.

Froese R., z.d. Ammodytes tobianus Linnaeus, 1758. http://www.fishbase.org/Summary/SpeciesSummary.php?ID=38\&AT=sandeel, geraadpleegd op 23 augustus 2017

Geelhoed S.C.V., Lagerveld S., Verdaat J.P. \& Scheidat M. 2014. Marine mammal surveys in Dutch waters in 2014. IMARES Report C180/14, 18p.

Gilles A., Viquerat S., Becker E.A., Forney K.A., Geelhoed S.C.V., Haelters J ., Nabe-Nielsen J., Scheidat M., Siebert U., Sveegaard S., van Beest F.M., van Bemmelen R. \& Aarts G. 2016. Seasonal habitat- based density models for a marine top predator, the harbor porpoise, in a dynamic environment. Ecosphere 7(6): e01367. 10.1002/ecs2.1367.

Haelters J., Kerckhof F., Jauniaux T. \& Degraer S. 2012. The grey seal (Halichoerus grypus) as a predator of harbour porpoises (Phocoena phocoena)? Aquat. Mamm. 38: 343-353.

Haelters J., Kerckhof F., van Neer A. \& Leopold M. 2015. Letter to the editor: Exposing grey seals as horses and scientist as human. Aquat. Mamm. 41: 351-353.

Hammond P.S., Bearzi, G., Bjørge, A., Forney, K., Karczmarski, L., Kasuya, T., Perrin, W.F., Scott, M.D., Wang, J.Y., Wells, R.S. \& Wilson, B. 2008. Phocoena phocoena. The IUCN Red List of Threatened Species. Geraadpleegd op 11 juli 2017 van, http://www.iucnredlist.org/details/17027/0.

Hammond P.S., Berggren P., Benke H., Borchers D.L., Collet A., Heide-Jørgensen M.P., Heimlich S., Hilby A.R., Leopold M.F \& Øien N. 2002. Abudance of harbour porpoise and other small cetaceans in the North Sea and adjacent water. J.Applie.Ecol. 39: 361-376.

Hammond P.S., Lacey C., Gilles A., Viquerat S., Börjesson P., Herr H., Macleod K., Ridoux V., Santos M.B., Scheidat M., Teilmann J., Vingada J. \& Øien N. 2017. Estimates of cetacean abundance in European Atlantic waters in summer 2016 from the SCANS-III aerial and shipboard surveys. https://synergy.standrews. ac. uk/scans3/files/2017/05/SCANS-III-design-based-estimates-2017-05-12-final-revised.pdf

Härkönen T. 1986. Guide to the Otoliths of the Bony Fishes of the Northeast Atlantic. Hellerup, Denmark: Danbiu ApS.

Hoekendijk J.P.A., Spitz J., Read, A.J., Leopold M.F. \& Fontaine M.C. 2017. Resilience of harbor porpoises to anthropogenic disturbance: must they really feed continuously? Marine Mammal Science, in druk. 
Jauniaux T., Garigliany M.M., Loos, P., Bourgain J.L., Bouveroux T., Coignoul F., Haelters J., Karpouzopoulos J., Pezeril S. \& Desmech D. 2014. Bite injuries of grey seals (Halichoerus grypus) on harbour porpoises (Phocoena phocoena). PLoS ONE 9(12): el08993. doi: 10.1371/journal. pone.0108993.

Jefferson T.A., Webber M.A \& Pitman R.L. 2015. Marine Mammals of the world. A Comprehensive guide to their identification. Second edition. Elsevier Inc. 326-329.

Kastelein R.A.,Helder-Hoek L. \& Jennings N. 2018. Seasonal changes in food consumption, respiration rate, and body condition of a male harbor porpoise (Phocoena phocoena). Aquatic Mammals 44: 76-91.

KeijI G.O., Begeman L., Hiemstra S., IJ sseldijk L.L., Kamminga P. \& Seal Centre Pieterburen. 2016. Cetaceans stranded in the Netherlands in 2008-2014. Lutra 59, (1-2): 75-107.

Kuiken T. \& Garcia Hartmann M. 1992. Draft standard protocol for the basic postmortem examination and tissue sampling of small cetaceans. In: Guidelines and rec. form. resulting from the 1st ECS workshop on cetacean pathology: dissection techniques and tissue sampling, Leiden, 13-14 Sep 1991. Bijl. ECS Newsletter No. 14.

Leopold M.F. 2015a. Eat and be eaten; Porpoise diet studies. PhD thesis, Wageningen University, Wageningen.

Leopold M.F. 2015b. Wat beweegt de bruinvis? This side of paradise (PowerPoint). Haren. http://thissideofparadise. nl/wp-content/uploads/2015/08/Leopold-30-Augustus-2015-This-side-ofparadise-Haren.pdf

Leopold M.F. \& C.J. Camphuysen 2006. Bruinvisstrandingen in Nederland in 2006: Achtergronden, leeftijdsverdeling, sexratio, voedselkeuze en mogelijke oorzaken. IMARES Rapport C083/06, NIOZ Report 2006, Wageningen IMARES en Koninklijk Nederlands Instituut voor Onderzoek der Zee, Texel.

Leopold M.F., van Damme C.J.G., Philippart C.J.M. \& Winter C.J.N. 2001 . Otoliths of North Sea fish: interactive guide of identification of fish from SE North Sea, Waddensea and adjacent fresh waters by means of otoliths and other hard parts. CD-ROM, ETI, Amsterdam.

Leopold M.F., Begeman L., van Bleijswijk J.D.L., IJsseldijk L.L., Witte H.J . \& Gröne A. 2015. Exposing the grey seal as a major predator of harbour porpoises.. Proc. Royal Soc. B. 282: 20142429

Linnaeus C. 1758-1759. Systema naturae per regna tria naturae : secundum classes, ordines, genera, species, cum characteribus, differentiis, synonymis, locis. Holmiae : Impensis Direct. Laurentii Salvii

Long D.J. \& Jones R.E. 1996. White shark predation and scavenging on cetaceans in the Eastern North Pacific Ocean. In: Klimley AP, Ainley DG, editors. The Biology of Carcharodon carcharias. San Diego: Academic Press, 293-307.

Martin A.R. 1996. The diet of harbour porpoises (Phocoena phocoena) in British waters. International Whaling Commission, SC/47/SM48, Cambridge, UK.

McArdle B.H. \& Anderson M.J . 2001. Fitting multivariate models to community data: a comment on distancebased redundancy analysis. Ecology 82: 290-297.

Morisaka T. \& Conner R.C. 2007. Predation by killer whales (Orcinus orca) an the evolution of whistle loss and narrow-band high frequency clicks in odontocetes. J. Evol. Biol. 20: 1439-1458.

Muus B.J., Nielsen J.G., Dahlstrøm P. \& Nyström B.O. 1999. Zeevissen van Noord- en West- Europa. Schuyt \& Co, Haarlem.

NOAA Fisheries: Office of Protected Resources. 2014. Harbor Porpoise (Phocoena phocoena), http://www.nmfs.noaa.gov/pr/species/mammals/cetaceans/harborporpoise.htm. Geraadpleegd op 11 juli 2017.

Read A. J. 1999. Harbour porpoise (Phocoena phocoena). Handbook of marine mammals Volume 6, Issue 1: 323-350.

Read A.J. \& Hohn A.A. 1995. Life in the fast lane: the life history of harbour porpoise from the Gulf of Maine. Mar. Mamm. Sci. 11: 423-440.

Recchia C.A. \& Read A.J. 1988. Stomach contents of harbour porpoises, Phocoena phocoena (L.), from the Bay of Fundy. Can. J. Zool. 67: 2140-2146.

Roller M., Gross S., Reckendorf A., Andreasen H., Wohlsein P. \& Siebert U. 2017. Fatal asphyxiation with laryngeal displacement caused by platvissen in harbour porpoises (Phocoena phocoena). Poster presented at 31st Ann. Conf. ECS, Middelfart, Denmark.

Santos M.B. 1998. Feeding ecology of harbour porpoises, common and bottlenose dolphins and sperm whales in the northeast Atlantic. PhD thesis, University of Aberdeen, Aberdeen, Scotland.

Santos M.B. \& Pierce G.J. 2003. The diet of harbour porpoise (Phocoena phocoena) in the Northeast Atlantic. Oceanography an Marine Biology: an Annual Review. 41: 355-390.

Saulitis E., Matkin C., Barret-Lennard L., Heise K. \& Ellis G. 2000. Foraging strategies of sympatric killer whale (Orcinus orca) population in Prince William Sound, Alaska. Mar. Mamm. Scie. 16: 94-109.

Schelling T., Steeg van der L.J. \& Leopold M.F. 2014. The diet of the harbour porpoises Phocoena phocoena in Dutch waters: 2003-2014. IMARES Report C136/14.

Spitz J., Trites A.W., Becquet V., Brind'Amour A., Cherel Y., Galois R \& Ridoux V. 2012. Cost of living dictates what whales, dolphins and porpoises eat: the importance of prey quality on predator foraging stratigies. PLoS ONE 7(11): e50096. doi:10.1371/journal. pone.0050096.

Stenson G. B. 2003. Harbor porpoise (Phocoena phocoena) in the North Atlantic: abundance, removals, and sustainability of removals. NAMMCO Scientific Publications 5: 271-302.

Stringell T., Hill D., Rees D., Rees F., Rees P., Morgan G., Morgan L. \& Morris C. 2015. Predation of harbour porpoises by grey seals in Wales. Aquat. Mamm. 41: 188-191

Tollit D.J., Heaslip S.G., Zeppelin T.K., J oy R., Call K.A. \& Trites A. W. 2004. A method to improve size estimates of walleye pollock (Theragra chalcogramma) and atka mackerel (Pleurogrammus monopterygius) 
consumed by pinnipeds: digestion correction factors applied to bones and otoliths recovered from scats. Fish. Bull. 102: 498-508.

Vinther M. 1999. Bycatches of harbour porpoises (Phocoena phocoena I.) in Danish set-net fisheries. J. Cetacean Res. Manage. 1, 2: 123-135.

Vinther M. \& Larsen F. 2004. Updated estimates of harbour porpoise (Phocoena phocoena) bycatch in the Danish North Sea bottom-set gillnet fishery. J. Cet. Res. \& Managem. 6: 19-24.

Vodden P. 1995. Predation on harbour porpoise by grey seals and bottlenose dolphins. Soundings (newsletter for Seawatch Foundation) 2, 4: 5-6.

Watt J., Pierce G.J. \& Boyle P.R. 1997. Guide to the identification of North Sea fish using premaxillae and vertebrae. ICES Coop. Res. Report No. 220, Copenhagen.

WDC. z.d. Harbour Porpoise (Phocoena Phocoena). http://uk. whales.org/species-guide/harbour-porpoise. Geraadpleegd op 11 juli 2017.

Williams T.M., Estes J.A., Doak D.F. \& Springer A.M. 2014. Killer appetites: assessing the role of predators in ecological communities. Ecology 85: 3373-3384.

Wilson D.E. \& Mittermeier R.A. 2014. Handbook of the Mammals of the World. 4: 295-297.

Wisniewska D.M., Johnson M., Teilmann J., Rojano-Doñate L., Shearer J., Sveegaard S., Miller L.A., Siebert U. \& Madsen P.T. 2016. Ultra-high foraging rates of harbor porpoises make them vulnerable to anthropogenic disturbance. Current Biology 26: 1441-1446.

WoRMS World Register of Marine Species. 2017. http://www. marinespecies.org/aphia. php?p=taxlist. Geraadpleegd op 10 augustus 2017 


\section{Dankwoord}

Dit rapport is aanvankelijk geschreven als een studentenrapport. Graag wil ik (Amy Mairo) mijn supervisor Mardik Leopold bedanken voor de steun en begeleiding tijdens dit project en voor het verder opwerken van mijn rapport tot een gezamenlijk WMR rapport. Ook Guido Keijl (Naturalis) en Anita van Nierop ( $\mathrm{VHL}$ ) wil ik bedanken voor de begeleiding tijdens de verwerking van maaginhoud en het assisteren met determinatie wanneer ik daar zelf niet uit kwam. Wij willen graag Lonneke IJ sseldijk en Lineke Begeman van de Universiteit Utrecht bedanken voor het feit dat we een sectie konden bijwonen, en voor het vergaren van de magen en de fysiologische data die gebruikt zijn in deze studie. Ook willen wij graag de vele vrijwilligers en studenten bedanken die hebben meegeholpen bij het verzamelen van bruinvissen en het verwerken van de data van voorgaande bruinvissen die gebruikt zijn in deze studie. 


\section{Verantwoording}

Rapport C032/18

Projectnummer: Helpdeskvraag HD 3510; BO-11-011.04-041, jaar 2014

Dit rapport is met grote zorgvuldigheid tot stand gekomen. De wetenschappelijke kwaliteit is intern getoetst door een collega-onderzoeker en het directielid van Wageningen Marine Research.

Akkoord:

Oscar Bos

onderzoeker

Handtekening:

Datum:

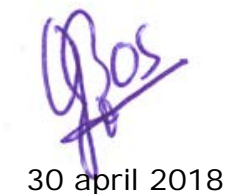

Akkoord:

Jakob Asjes

MT-lid

Handtekening:

Datum:

30 april 2018 
Wageningen Marine Research

$\mathrm{T}:$ +31 (0)317480900

E: marine-research@wur.nl

www. wur.nl/marine-research

Visitors address

- Ankerpark 271781 AG Den Helder

- Korringaweg 5, 4401 NT Yerseke

- Haringkade 1, 1976 CP Ijmuiden
Wageningen Marine Research is the Netherlands research institute established to provide the scientific support that is essential for developing policies and innovation in respect of the marine environment, fishery activities, aquaculture and the maritime sector.

Wageningen University \& Research is specialised in the domain of healthy food and living environment.

The Wageningen Marine Research vision:

'To explore the potential of marine nature to improve the quality of life.

The Wageningen Marine Research mission

- To conduct research with the aim of acquiring knowledge and offering advice on the sustainable management and use of marine and coastal areas.

- Wageningen Marine Research is an independent, leading scientific research institute.

Wageningen Marine Research is part of the international knowledge organisation Wageningen UR (University \& Research centre). Within Wageningen UR, nine specialised research institutes of Stichting Wageningen Research (a Foundation) have joined forces with Wageningen University to help answer the most important questions in the domain of healthy food and living environment. 